\title{
EL PODER REAL EN LA MURCIA ARAGONESA A TRAVÉS DEL OFICIO DE LA PROCURACIÓN, 1296-1304
}

\author{
José Vicente CABEZUELO PLIEGO \\ Universidad de Alicante
}

En la primavera de 1296 Jaime II llevó a cabo una campaña militar por tierra y por mar que le permitió en breve tiempo conquistar el reino de Murcia castellano ${ }^{1}$. Frente a otros momentos en los que las relaciones entre las coronas de Castilla y Aragón propiciaban el enfrentamiento armado, no fueron, sin embargo, los primeros años del reinado de Jaime II tiempos que presupusiesen inestabilidades diplomáticas conducentes a crisis bélicas. Aunque lo cierto es que las tierras murcianas habian de ser, casi necesariamente, fuente de conflicto entre ambas potencias peninsulares atendiendo a que en ellas convergían las líneas de expansión de la cristiandad hispana frente al Islam, apareciendo la región desde un principio como objetivo fundamental ${ }^{2}$. Pese a su inicial dominio castellano, la Corona de Aragón siempre tuvo en consideración, ora subjetiva ora objetivamente, este espacio, que defendió como suyo e incluso

1 Acerca de la conquista del reino de Murcia por Jaime II cfr. ESTAL GUTIÉRREZ, J.M. del, Conquista y anexión de las tierras de Alicante, Elche, Orihuela y Guardamar al Reino de Valencia por Jaime II de Aragón (1296-1308). Alicante Medieval en la Proyección expansionista de Aragón, desde la hegemonía castellana a su incorporación formal al Reino de Valencia (1243-1308), Alicante, 1982. ld., Corpus Documental del reino de Murcia bajo la soberania de Aragón (1296-1304/5). Colección de Documentos Medievales Alicantinos //1, Alicante, 1985. Id., El reino de Murcia bajo Aragón (12961305). Colección documental del medievo alicantino. Corpus Documental $1 / 2$, Alicante, 1990. FERRER i MALLOL, M‥T., «Notes sobre la conquesta del regne de Múrcia per Jaume II (1296-1304)", en Homenatge a la memória del Prof. Emilio Sáez. Aplec d'estudis dels seus deixebles y col.laboradors, Barcelona, 1989, pp. 27-44.

2 BEJARANO RUBIO, A., «La frontera del reino de Murcia en la política castellano-aragonesa del siglo XIll', en Alfonso X el Sabio, vida, obra y época, I, Madrid, 1989, pp. 199-212. 
repobló con sus gentes ${ }^{3}$. Algunos contemporáneos de los acontecimientos creyeron encontrar razones que avalaban el interés catalano-aragonés por Murcia. Lo cierto es que si la política de Jaime I aparentemente reforzó la línea de Almizra como mojón meridional con la vecina Castilla, la de sus sucesores en el trono se orientó a su traslado hasta el contacto directo con Granada. Pedro el Grande y Alfonso el Liberal contaron con una importante baza a su favor, los infantes de la Cerda, quienes, protegidos desde 1277 en la Corona de Aragón de su tío Sancho IV, obtuvieron en ella los apoyos necesarios para intentar recuperar el trono castellano a cambio de la cesión del reino de Murcia. El primer paso lo dio Alfonso III, quien al permitir la coronación de Alfonso de la Cerda en Jaca como rey de Castilla obtuvo en compensación el reino de Murcia en 1289. Este acto nominal fue llevado al terreno de la práctica por Jaime II, cuando, solventados todos sus problemas internacionales, se decidió por la recuperación de ese territorio.

Incorporado el reino de Murcia a la soberanía del rey Justo como un territorio más -así lo pone de relieve su intitulación durante el período en cuestión: «... rex Aragonum, Valencie, Murcie ac comes Barchinone..."一, Jaime II aplicó en él el mismo sistema de administración pública utilizado en el resto de sus dominios, quedando obviamente relegado el castellano. Los gobiernos municipal y territorial fueron ordenados empleando la fórmula política que regía en la Corona de Aragón, y así, mientras que en las villas los tres pilares básicos de su gobierno eran Jurados-Justicia-Consejo, el espacio regnícola quedó desde el punto de vista gubernativo y administrativo en manos de un procurador real y de un baile general, encargados respectivamente del gobierno y de la administración del real patrimonio, ambos bajo el control directo del rey ${ }^{4}$. No se innovó, pues, a la hora de proceder al reordenamiento político del nuevo reino.

Conviene recordar que la conquista del espacio murciano fue una acción personal del rey de Aragón, quien cargó sobre sus hombros todo el peso de la campaña llegando incluso a poner en peligro su vida en más de una ocasión. Lo cierto es que fue durante su estancia en estas tierras, todavía inconclusa la conquista, cuando asentó las bases del gobierno territorial murciano en su ausencia. El 31 de mayo de 1296, recién conquistada la villa de Mula, fue creada la Bailía General bajo la dirección de Bernat Colomet ${ }^{5}$. Unos días antes, tras la rendición de la capital del reino, era la

3 Acerca de este tema cf. TORRES FONTES, J., La reconquista de Murcia en 1266 por Jaime I de Aragón, Murcia, 1987, en concreto de la página 109 en adelante.

4 FERRER i MALLOL, Ma.T., "La Batllia General de la part del regne de València dellà Xixona», en Anales de la Universidad de Alicante. Historia Medieval, 6, Alicante, 1987-1988, pp. 279-309. Id., Organització i defensa d'un territori fronterer. La Governació d'Oriola en el segle XIV, Barcelona, 1990, pp. 3-59.

5 Con un salario de dos mil sueldos anuales. ACA, C, reg. 340 , f. 94 r. 
Procuración la institución creada y concedida a un hermano de Jaime II, Jaime Pérez ${ }^{6}$. Magistratura sobre la que vamos a reflexionar en estas páginas.

El origen y desarrollo de la Procuración en la Corona de Aragón como institución de gobierno estuvo íntimamente ligado a la expansión territorial y a la imposibilidad del príncipe para proceder personalmente al control político y administrativo de los nuevos espacios ${ }^{7}$. A fin de solventar estos problemas se procedió al empleo de fórmulas gubernativas de carácter público basadas en la idea de la representación ${ }^{8}$, apareciendo entonces delegados reales al frente de dichas entidades con la misión principal de administrar justicia y proceder a su gobierno en nombre del promotor ${ }^{9}$. De ahí que algún foralista, caso del aragonés Bardají, opinase con bastante razón que tales funcionarios fueron creados por el rey, y nunca por ley de ningún tipo ${ }^{10}$.

Murcia y su reino quedaron convertidos de inmediato en una Procuración, en un distrito administrativo como los existentes en el resto de tierras de la Corona de Aragón sustentados en territorios históricos con entidad propia: reinos, condados. Si bien, no hubo que esperar la ausencia del rey, como sucediese en el reino de Valencia ${ }^{11}$, para conocer de este oficio en Murcia. Cargo, por otro lado, de muy similares características al existente en estas tierras durante la dominacjón castellana: el adelantado, tal y como ha afirmado J. M. Pérez-Prendes ${ }^{12}$, y como creyeron los habitantes de esas tierras, caso de las gentes de Novelda, aljama situada en el espacio que conquistara

6 ACA, C, reg. 340, f. 105v. (1296, mayo, 23). ESTAL. GUTIÉRREZ, J.M. del, Conquista y anexión de las tierras..., p. 247. Id., El reino de Murcia bajo Aragón... l/1, doc. nº 91. FERRER i MALLOL, Mª.T, Organització i defensa..., p. 15 y doc. $n^{\circ} 4$.

7 LALINDE ABADÍA, J., "Ensayo de tipología orgánica de la administración en la historia de España", estratto dagli Annali della Fondazione italiana per la storia amministrativa, 4, Milano, 1967, pp. 10-11 y 13-14. CABEZUELO PLIEGO, J.V., Poder público y administración territorial en el reino de Valencia, 1239-1349. El oficio de la Procuración, Tesis Doctoral inédita, Facultad de Filosofía y Letras, Universidad de Alicante, 1996, I, pp. 113-121.

8 LALINDE ABADÍA, J., "Virreyes y lugartenientes medievales en la Corona de Aragón", en Cuadernos de Historia de España, XXXI-XXXII, Buenos Aires, 1960, p. 99. Id., Derecho histórico Español, Barcelona, 1981, p. 322. PÉREZ BUSTAMENTE, «El Gobierno y la administración de los territorios de la Corona de Aragón bajo Jaime I el Conquistador y su comparación con el régimen de Castilla y Navarra", en $X$ Congreso de Historia de la Corona de Aragón, Zaragoza, 1980, pp. 515-516.

9 MONSALVO ANTÓN, J.Ma., "Poder político y aparatos de estado en la Castilla bajomedieval. Consideraciones sobre su problemática», en Studia Historica, IV, Salamanca, 1986, p. 121.

10 BARDAXI, I. de, Tractatus de officio Gubernationis seu Procurationis Generalis regni Aragonum, Zaragoza, 1592, secunda quaestio, $\mathrm{n}^{\circ} 1$, 3, 4-6 y quarta quaestio, $\mathrm{n}^{\circ} 6$.

11 CABEZUELO PLIEGO, J.V., Poder público y administración territorial..., I, p. 128.

12 «De esta forma resulta que "adelantado" viene a ser, dentro de la estructura político-administrativa del reino castellano, algo al modo del "locum tenens", del "gerens vices", que se va a usar en Cataluña». PÉREZ-PRENDES Y MUÑOZ DE ARRACÓ, J.M., “Fazer justicia. Notas sobre actuación gubernativa medieval», en Moneda y crédito. Revista de Economía, Homenaje a Don José Antonio Rubio Sacristán, II, 129, p. 77. Acerca de los adelantados murcianos anteriores a la conquista aragonesa, cf. TORRES FONTES, J., "Los adelantados mayores del reino de Murcia en el siglo XIII», en Colección de Documentos para la Historia del Reino de Murcia, V, Documentos de Fernando IV, Murcia, 1980, pp. XV-XXII. 
Jaime II en 1296, quienes a finales del siglo XIV todavía asimilaban Adelantamiento con lo que ellos denominaban «offici de Governador» ${ }^{13}$, o de procurador, para entendernos mejor.

Las amplias competencias con que contó hicieron del oficio el más importante tras la Curia regia ${ }^{14}$, pues sus titulares, pese a no contar con poderes absolutos, se convirtieron en las cabezas visibles de la administración civil, militar y judicial del territorio que administraban; poder que en algún momento vieron acrecentado tras la obtención de comisiones para proceder en determinados asuntos que no podían atender de ordinario $^{15}$.

Pese a que los estudios sobre la Procuración dentro de los territorios que compusieron la antigua Corona de Aragón no han sido hasta la fecha objetivo preferencial en la investigación histórica ${ }^{16}$, curiosamente la Procuración del reino de Murcia, pese a sus escasos ocho años de existencia, cuenta con uno de los análisis más completos, al tiempo que pioneros, sobre la temática. Empleando un discurso diacrónico su autora, Ma .T. Ferrer i Mallol, conocedora como nadie de la problemática histórica de estas tierras, reflexiona acerca del devenir de la magistratura en cuestión a través de la acción de gobierno de sus titulares. Es por ello que nos sentimos liberados de tratar de forma prolija en estas páginas ciertos aspecios sometidos a análisis por la citada historiadora. Nuestra intención será, más bien, la de acercarnos a la magistratura desde una perspectiva sincrónica y globalizadora que analice características generales y privativas al tiempo que competencias y limitaciones a sus actuaciones antes que trayectorias personales de quienes rigieron sus destinos.

\section{CARACTERES GENERALES DE LA PROCURACIÓN MURCIANA}

Cuando aparece la Procuración en el reino de Murcia se trataba de un oficio consolidado en la Corona de Aragón, aunque relativamente. Ya desde tiempos de Jaime 1 los dominios del rey fueron gobernados a través de procuradores. Del mismo modo actuaron sus sucesores, Pedro III y Alfonso III. Pero la magistratura, si la analizamos en su estructura general, o las magistraturas, si lo hacemos desde una óptica territorial, lejos de presentar un modelo unitario de funcionamiento se mostraban muy heterogéneas en lo estructural y en lo espacial, pues tan pronto encontramos momen-

13 CABEZUELO PLIEGO, J.V., Poder público y administración territorial..., I, pp. 115-116.

14 MATHEU i SANZ, LI., Tractatus de regimine urbis et regni Valentiae, Valencia, 1654, cap. II, sent. III, $\mathrm{n}^{\circ} 42$.

15 Por ejemplo, la concesión de salvoconductos, como la otorgada por Jaime Il a Bernat de Sarrià en la primavera de 1300 en favor de los vecinos de Lorca y Mula, poblaciones en esos momentos rebeldes, que quisiesen pasar al servicio del rey de Aragón. ACA, C, reg. 197, f. 99r. (1300, abril, 1).

16 Es curioso, a la vez que sintomático, que transcurridas más de tres décadas el trabajo de J. Lalinde sobre la Gobernación siga siendo obra de referencia obligada a la hora de plantearse cualquier estudio sobre el tema en cualquier territorio de la Corona de Aragón, no sólo por su vigencia científica, que la posee, sino también porque es la única obra existente que aborda y analiza el problema. LALINDE ABADÍA, J., La Gobernación General en la Corona de Aragón, Zaragoza, 1963. 
tos en los que el sistema procuratorial tiende a la unidad de gobierno, como sucede en Aragón, Cataluña y Valencia a principios de las décadas de 1270 y 1290 con hijo y nieto respectivamente de Jaime $\mathrm{l}$, ambos infantes de nombre Pedro, como otros, en ese mismo espacio temporal, en que los territorios pierden tal conexión y quedan administrados por personajes vinculados tan sólo al rey, e incluso momentos en que el marco geopolítico de aplicación del modelo procuratorial, reinos y condados, se quebranta para duplicarse, aunque por breve tiempo, como sucede en Valencia donde en 1286 el reino queda dividido por la línea del Júcar en dos distritos procuratoriales, citra et ultra Xucharum ${ }^{17}$.

Si esto es en cuanto a la institución, otro tanto ocurre en lo referente a sus titulares. En este punto es conveniente advertir que prácticamente hasta finales del siglo XIII la magistratura conoció momentos en que tuvo carácter de Lugartenencia en el pleno sentido jurídico del término, con lo que quienes la desempeñaban no eran sino alter ego reales en el territorio a regentar ${ }^{18}$. Mientras que en otros tal intitulación, originaria por otro lado del oficio, evoluciona en concepto hasta el punto de solaparse y convirtiese en sinónimo perfecto de Procuración, de ahí que durante todo el período en cuestión hablemos de locum tenens y procurator refiriéndonos incluso a un mismo oficial, como ocurre en Valencia con Pere Ferrando, nominado en 1267 «procuratorem sive tenentem locum nostrum in eodem regno" ${ }^{19}$.

En consecuencia, cuando a mediados de la última década del Doscientos acontece la conquista e incorporación murciana a la Corona de Aragón y la introducción en este nuevo territorio de la Procuración como fórmula política, la magistratura, como concepto, se hallaba en una fase todavía formativa. Va a ser precisamente Jaime II quien en estos momentos establezca las bases sobre las que habría de asentar la institución. Y así, de un momento, designado por Lalinde como «sistema procuratorial inorgánico» en cuanto carente de normativa establecida, se alcanzó entre 1299 y 1302 a lo que también el citado historiador denominó como «régimen de la Procuración General» y que nacía para dar cobertura legal a la participación del primogénito en las tareas de gobierno. El heredero al trono, convertido en procurador general de la Corona, pasaba a administrar los distintos territorios a través de representantes vinculados a su persona, denominados gerentes vices procuratoris o portants veus de procurador, con las mismas funciones que los antiguos procuradores designados por el rey. Sin embargo, esta nueva forma gubernativa no se aplicó de modo instantáneo en todos los territorios de la Corona, pues ni Murcia ni Valencia quedaron incluidas dentro de ese régimen. Frente a lo que acontecía a principios del Trescientos en Aragón y Cataluña, donde Lope de Gurrea y Bernat de Fonollar aparecen como vicegerentes del primogénito, en Valencia y en Murcia los titulares de la Procuración, Bertran de Canelles y Pere de Montagut, nominados en abril de 1303, lo eran por y en nombre

17 lbidem, pp. 28-38.

18 LALINDE ABADÍA, J., «Virreyes y Lugartenientes medievales...», pp. 99-105. Id., La Gobernación General..., pp. 35-37. Para el reino de Valencia cf. CABEZUELO PLIEGO, J.V., Poder público y administración territorial..., l, pp. 203, 254 y II, pp. 753-757.

19 CABEZUELO PLIEGO, J.V., Poder público y administración territorial..., I, p. 158. 
del rey ${ }^{20}$. De ahí que el reino de Murcia nunca conociese del nuevo sistema de la Procuración General, ni tampoco el de Valencia hasta 1309, manteniéndose ambos durante todo ese tiempo en la misma dinámica de vinculación en exclusividad con el rey. A la pregunta de por qué no se introdujo el nuevo sistema en todos los territorios al unísono, quedando fuera Murcia y Valencia, en la actualidad sólo se puede responder con hipótesis. Una de ellas, con posibles visos de veracidad, quizá fuese la inestabilidad bélica de ambos reinos, sobre todo el murciano, frente a toda clase de peligros exteriores, "Tanto como la lógica de estrenar un sistema administrativo en el marco de unos territorios muy asentados en sus raíces, política e incluso geográficamente, como era el caso de Aragón y Cataluña, frente a espacios inestables en los que, quizá otra vez, se requiriese la efectividad de los modelos ${ }^{21}$.

\section{Número y condición de los procuradores murcianos}

Cinco fueron los oficiales que ocuparon la Procuración del reino de Murcia entre los veranos de 1296 y de 1304: Jaime Pérez ${ }^{22}$, Jaime de Jérica ${ }^{23}$, Bernat de Sarrià ${ }^{24}$, Bernat de Cruïlles ${ }^{25}$ y Pere de Montagut ${ }^{26}$. Número elevado si tenemos en cuenta la brevedad del dominio aragonés en estas tierras, pero que se entiende al tratarse de cargos de responsabilidad sujetos al beneplácito real, con lo que el rey removía discreccionalmente a sus titulares, bien porque el momento requiriese de un hombre con características distintas a las ofrecidas por quien en esos instantes ocupaba la magistratura, o bien para ofrecerles otros destinos ${ }^{27}$. A excepción de Jaime de Jérica,

$20 \ll . .$. comitimus sive comendamus vobis officium Procuracionis regni nostri... Ita quod vos sitis procurator noster in ipso regno et exerceatis bene et fideliter ad honorem et fidelitatem nostram ipsum officium", es lo que se lee en el nombramiento de ambos. Cfr. ACA, C, reg. 231, f. 53r.-v. (1303, abril, 29). FERRER i MALLOL, Mํ.T., Organització i defensa..., doc. no 28 para el nombramiento del procurador murciano, y ACA, C, reg. 231, f. 35r. (1303, abril, 30), para el valenciano.

21 CABEZUELO PLIEGO, J.V., Poder público y administración territorial..., I, pp. 347-348.

22 ACA, C, reg. 340, f. 87r. (1296, mayo, 23). ESTAL GUTIÉRREZ, J.M. del, El reino de Murcia... $1 / 1$, doc. $\mathrm{n}^{\mathrm{o}} 91$.

23 ACA, C, reg. 196, f. 183r. (1298, abril, 9). FERRER i MALLOL, Ma.T., Organització i defensa..., doc. $n^{0} 14$.

24 Apéndice documental, doc. no 4. FERRER i MALLOL, Mำ.T., Organització i defensa..., doc. nº 16.

25 ACA, C, reg. 231, f. 51r. (1303, abril, 3). LALINDE ABADÍA, J., La Gobernación General..., doc. $\mathrm{n}^{\mathrm{0}} \mathrm{XI}$.

26 ACA, C, reg. 231 , f. 53r.-v. (1303, abril, 29). FERRER i MALLOL, Mª.T., Organització i defensa..., doc. $\mathrm{n}^{\circ} 28$.

27 Esto fue lo sucedido con Bernat de Sarrià, a quien Jaime II destituye tras haber recibido innumerables quejas de sus gobernados, y asi se lo comunica en carta privada. ACA, C, reg. 231, ff. 51V. 52 r. (1303, abril, 3). Si bien, la razón oficial que ofrece el rey a su sustituto en la Procuración, Bernat de Cruilles, es que le ha removido del cargo porque le necesitaba a su lado. ACA, C, reg. 231, f. 51r. (1303, abril, 3). Cf. LALINDE ABADÍA, J., La Gobernación General..., docs. no XI y XII. ESTAL GUTIÉRREZ, J.M. del, El reino de Murcia bajo Aragón... l/1, docs. $\mathrm{n}^{\circ} 229$ y 230. FERRER i MALLOL, M. ${ }^{a}$ T, Organització $i$ defensa..., pp. $42-43$ y doc. no 25. CABEZUELO PLIEGO, J.V., Poder público $y$ administración territorial..., II, pp. 662-663. 
el resto fueron procuradores privativos del territorio murciano, compartiendo el de Jérica su responsabilidad con el reino de Valencia. Asimismo, todos ellos contaron con idénticas prerrogativas procuratoriales, salvando la excepción de Bernat de Cruilles, sustituto de Bernat de Sarrià, quien alcanzaba el oficio en la primavera de 1303 investido de caracteres de lugarteniente ${ }^{28}$.

a. Obligación del procurador era la de hacer residencia personal en el territorio que hubiera de administrar. Muy pocos datos son los que tenemos a este respecto acerca de los procuradores murcianos. Imaginamos que Murcia sería la ciudad elegida a tal efecto, por razón de su condición capitalina, como lo era Valencia, aun desconociendo el emplazamiento exacto de la casa-residencia y del inmueble habilitado como Curia o tribunal procuratorial - de no ser el mismo-; ello pese a la obligatoriedad de estos oficiales de viajar por todo el reino. Únicamente conocemos una noticia tardía, de 1303, por la que Jaime II ordenaba al entonces procurador Pere de Montagut recibir en su nombre y custodiar el castillo de Molina. Además de proveer lo necesario para su defensa, el rey quería que Montagut llevase su residencia hasta él para custodiarlo mejor $^{29}$. Otros procuradores, como Jaime de Jérica o Bernat de Sarrià, también obtuvieron alcaidías de castillos - Orihuela y Alicante respectivamente- durante su gestión al frente de la Procuración, que en algún caso abandonaron finalizada ésta ${ }^{30}$, desconociendo si residieron o no en ellos ${ }^{31}$. Encontramos paralelos a este tipo de residencia castrense en la vecina Valencia, en donde Pere de Queralt obtuvo las casas del castillo de Corbera para morar con su familia mientras ocupase el cargo; así como

28 Podría entenderse que se trata de dos oficios diferentes, desde la teoría del Derecho, dado que Jaime II en ningún momento entrega a Bernat de Cruilles la Procuración del reino de Murcia sino «nostre lloc en aquell regne». Si bien, equipara perfectamente ambas situaciones cuando indica que el nombramiento alcanzado por Cruilles deviene por la imposibilidad de que pueda quedar vacante la Procuración murciana. ACA, C, reg. 231, f. 51v. (1303, abril, 3). ESTAL GUTIÉRREZ, J.M. del, El reino de Murcia bajo Aragón... $/ 1 /$, doc. $\mathrm{n}^{\circ} 231$. Es claro, entonces, que aun con distinta intitulación y posiblemente con alguna competencia más, Bernat de Cruïlles habría de realizar el mismo trabajo que sus antecesores los procuradores, pues su misión fundamental era administrar justicia y mantener el territorio en paz.

Es importante referir que la presencia de Bernat de Cruilles en suelo murciano no derivó de su nombramiento como lugarteniente real, sino que fue anterior a éste. En febrero de ese mismo año Jaime II envía a este noble a Murcia para coordinar la defensa del reino ante un supuesto ataque castellano, comunicando su presencia al procurador y a las autoridades municipales murcianas para que le reconociesen tal función. La entrega de esa misión a Cruilles, que podia desempeñar pertectamente el procurador por ser parte de su cometido, hacía que los días de Bernat de Sarrià al frente de la institución estuvisen contados. ACA, C, reg. 126, ff. 285v.-286r. (1303, febrero, 10).

29 Apéndice documental, doc. $n^{0}$ 7. FERRER i MALLOL, Mํ. T., Organització i defensa..., p. 52.

30 Como sucedió al señor de Jérica, que hubo de restituir la plaza a Bernat de Cruillles y ésta hacer lo propio a Guillem de Vilaragut, que era a quien el rey había designado como alcaide. ACA, C, reg. 197, f. 99v. (1300, abril, 1).

31 Bernat de Sarrià parece que no residió en Alicante, donde tenía un sustituto. FERRER i MALLOL, Ma ${ }^{a}$.T., "La tinença a costum d’Espanya en els castells de la frontera meridional valenciana (segle XIII)», en Miscel/lània de Textos Medievals, 4, Barcelona, 1988, p. 17. 
también en las tierras dellà Sexona, donde existía una estrecha vinculación entre Procuración y alcaidía de la fortaleza oriolana ${ }^{32}$.

b. Era igualmente obligación de los oficiales adscritos a la Procuración murciana el juramento de la observancia de los fueros y privilegios del territorio sujeto a su administración. Así quedó establecido por Jaime II en Murcia cuando al confirmar distintos privilegios y franquezas de la capital del reino a solicitud de sus habitantes, en agosto de 1296, dispuso que cada procurador al principio de su administración y gobierno jurase ante el Consell de la ciudad de Murcia, en el altar de la iglesia de Santa María "sedis Murcie» el cumplimiento y la defensa de dicha normativa ${ }^{33}$. Era costumbre que los titulares de la Procuración hiciesen jura de reconocimiento de la legislación vigente así como de privilegios, franquezas, usos y costumbres privativos de cada uno de los territorios ${ }^{34}$, prestación que se consideraba garantía sobre su buena gestión ${ }^{35}$. Su no ejecución «implicaba la ilegalidad de las acciones emprendidas en nombre del oficio ${ }^{36}$ al tiempo que su remoción de él. La conexión en este punto con el reino de Valencia es total, pues aquí el procurador también había de realizar el acto de jura ante Consell de la capital del reino si hablamos de la Procuración citra, y ante el de Orihuela si nos referimos a las tierras ultra Sexonam ${ }^{37}$. Del otro tipo de garantía, la prestación de fermançes e manposters a fin de rendir cuentas ante sus gobernados una vez finalizado el ejercicio del cargo, no tenemos noticia alguna, aunque no dudamos de su existencia ${ }^{38}$.

c. Los oficiales de la Procuración vieron satisfecha la prestación de sus servicios con la recepción de un salario anual sobre diversos conceptos, pudiendo además obtener cantidades extraordinarias a añadir al monto salarial que no eran más que incrementos encubiertos del mismo, tal y como ocurría en la Procuración valenciana ${ }^{39}$. Solamente conocemos una noticia, aunque ya tardía, donde se refleja el salario anual del regente de la magistratura murciana, que puede servir de paralelo a la hora de extrapolarlo al resto de gobiernos procuratoriales, aunque con las lógicas prevenciones, como ocurre en la vecina Valencia donde el emolumento procuratorial no alcanza una homogeneidad numérica ni de procedencia hasta la década de 1320 , cuando ya el reino se ha incorporado plenamente al régimen de la Procuración General. Se trata

32 CABEZUELO PLIEGO, J.V., Poder público y administración territorial.., II, p. 675. FERRER i MALLOL, Má.T., «La tinença a costum d'Espanya...», pp. 16-18 y 47-48.

33 ACA, C, reg. 194, ff. 226r.-227r. (1296, agosto, 3).

34 Para Valencia cf. CABEZUELO PLIEGO, J.V., Poder público y administración territorial..., Il, pp. 664-671.

35 LALINDE ABADÍA, J, Los medios personales de gestión del poder público en la Historia Es-

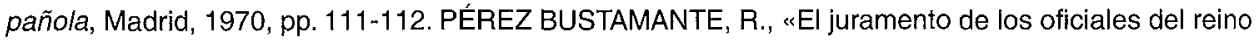
de Castilla, 1252-1474", en Moneda y Crédito. Revista de Economia, Homenaje a Don José Antonio Rubio Sacristán, Madrid, 1974, p. 211.

36 CABEZUELO PLIEGO, J.V., Poder público y administración territorial..., II, p. 667.

37 Ibidem, pp. 668-669.

38 Acerca del control sobre los oficiales de la Procuración valenciana cfr. ibídem, II, pp. 942-952.

39 Ibídem, II, pp. 679-713. 
de Pere de Montagut, a quien se le concede un salario anual de siete mil sueldos, más una cantidad extraordinaria de mil sueldos a añadir a esa suma mientras desempeñase el oficio ${ }^{40}$.

\section{Defender y juzgar: competencias del oficio de la Procuración}

La Procuración del reino de Murcia, al igual que sus paralelos en el resto de territorios de la antigua Corona de Aragón, fue creada para que desde ella se velase por la integridad territorial del espacio administrado, la seguridad interior al tiempo que «la defensa del buen estado de la cosa pública y de los intereses del rey a través de una intervención pacificadora al tiempo que punitiva" que "permitió a sus titulares actuar de una u otra forma sobre prácticamente todos los habitantes del reino, naturales 0 foráneos, moros, cristianos o judíos, hombres o mujeres, clérigos o laicos, realengos o señoriales $"{ }^{41}$. Con el fin de poner en práctica tales tareas, los reyes dotaron al oficio de amplios poderes, convirtiéndole en el vértice de la administración pública regnícola. A tal amplitud en el terreno de las competencias se unía para magnificarla la arbitrariedad con la que los oficiales de la Procuración ejercían su oficio. Será precisamente en estos instantes, en los albores del reinado de Jaime II, cuando desde la Curia regia se procediese, muy tibiamente, a marcar los perfiles jurisdiccionales de la magistratura. La breve andadura de la Procuración murciana conoció de esta política de mayor control real, si bien las características sociopolíticas del nuevo reino, en pie de guerra y con una numerosa población castellana hacia la que la nueva autoridad mostraba sus reservas, y no gratuitamente ${ }^{42}$, conferían a la Procuración una potencialidad jurisdiccional quizá mayor que en otros reinos, o si no eso una mayor permisibilidad por parte del poder real frente a acciones de dudosa justificación teórica de parte del procurador.

Del análisis de los nombramientos procuratoriales murcianos entre 1296 y 1304 sólo derivan rasgos generales de su quehacer oficial, mientras que ya en un terreno

40 ACA, C, reg. 231, f. 53v. (1303, abril, 29). A este mismo oficial, tras la partición del reino de Murcia en Torrellas, se le redujo el sueldo a la mitad, dado que era la mitad del territorio la que había de atender. ACA, C, reg. 231, f. 56r.-v. (1304, diciembre, 7). FERRER i MALLOL, Ma.T., Organització $i$ defensa..., doc. $\mathrm{n}^{\circ} 45$.

41 CABEZUELO PLIEGO, J.V., «Reflexiones en torno al oficio de la Procuración como instrumento de la acción regia para el gobierno político del reino de Valencia. 1239-1348», en Anales de la Universidad de Alicante. Historia Medieval, 10, Alicante, 1994-1995, p. 23.

42 La existencia de enemigos de Jaime II dentro del territorio murciano, que salian ocultamente del reino hacia Castilla para tratar contra los intereses del rey de Aragón, así como la entrada, también clandestina, de castellanos a Murcia con el mismo propósito, es un hecho desde la conquista, quedando los oficiales de la Procuración con la responsabilidad de descubrirlos y castigarlos. ACA, $C$, reg. 112 , f. 28v. (1298, junio, 19). Los peligros que suponía a la estabilidad política del nuevo reino la existencia de una población hostil llevaron a Jaime II a tomar una drástica solución: la expulsión de todos los castellanos del territorio murciano, aunque con las lógicas excepciones; medida aplaudida por el entonces procurador Bernat de Sarrià. ACA, C, reg. 118, f. 15r.-v. (1301, febrero, 21). FERRER i MALLOL, Ma.T., Organització i defensa..., p. 34 y doc. no 19. 
más particular a través del análisis de sus actuaciones concretas podemos construir una casuística de intervenciones privativas ex oficio. Desde el primero de los parámetros la misión principal de la institución sería militar y judicial. Así se desprende de la primera credencial de nombramiento que conocemos, la de Jaime de Jérica de abril de $1298^{43}$, donde se apunta la facultad para conocer de las segundas apelaciones, tal y como correspondía al oficio por haberlas detentado sus predecesores en el cargo, así como también la obligatoriedad de observar el derecho y hacer justicia. Por recibir nombramiento sobre los reinos de Valencia y Murcia, entendemos que al hablar de predecesores se entiende valencianos y murcianos. De Jaime Pérez, primer procurador del reino de Murcia, no tenemos la carta de promoción al cargo, pero sí de su antecesor valenciano, Jaspert de Castellnou, quien recibe la Procura cuatro meses después que Jaime Pérez, y a quien igualmente se le otorgan las segundas apelaciones $^{44}$, por lo que pensamos que Jaime Pérez también contaría con ellas. A toda esa carga judicial se añade también la castrense, dado que en la notificación que Jaime II dirigió a Murcia acerca del nombramiento del señor de Jérica como nuevo procurador del territorio subrayaba su carácter de «procuratorem et gubernatorem ac defensorem» y su función militar — «ut regnum nostrum Murcie ab hostibus potenter et viriliter deffendatur et possit in statu tranquillo et pacifico remanere" - ${ }^{45}$. El nombramiento de Bernat de Sarrià de abril de 1300 va en la misma dirección ${ }^{46}$. Sin embargo, no los de sus sucesores, pues ni en el de Pere de Montagut ${ }^{47}$, ni en el de Bernat de Cruïlles ${ }^{48}$ hay mención explícita al conocimiento de las segundas apelaciones ${ }^{49}$, aunque recordemos que este último tenía carácter de lugarteniente y ni siquiera llegó a ejercer como tal.

Defender y juzgar eran, como queda dicho, los principales cometidos de los regen-

43 ACA, C, reg. 196, f. 183r. (1298, abril, 8). FERRER i MALLOL, Ma.T., Organització i defensa..., doc. $n^{0}$ 14. CABEZUELO PLIEGO, J.V., Poder público y administración territorial..., I, p. 261 y II, p. 764 $y$ doc. $\mathrm{n}^{\circ} 47$.

44 ACA, C, reg. 194, f. 284r. (1296, octubre, 8). CABEZUELO PLIEGO, J.V., Poder público y administración territorial..., I, p. 255 y II, p. 764 y doc. $\mathrm{n}^{\mathrm{o}} 45$.

45 ACA, C, reg. 111, f. 295r. (1298, mayo, 16). TORRES FONTES, J., Colección de Documentos para la Historia del reino de Murcia, II, Documentos del siglo XIII, Murcia, 1969, doc. ํㅡ CXXXI. ESTAL GUTIÉRREZ, J.M. del, El reino de Murcia bajo Aragón... l/1, doc. $\mathrm{n}^{0} 163$.

46 Apéndice documental, doc. $n^{\circ}$ 4. FERRER i MALLOL, Mํ.T., Organització $i$ defensa..., p. 23 y doc. $n^{\circ} 16$.

$47 \mathrm{Ni}$ en su primer nombramiento como procurador del reino de Murcia -ACA, C, reg. 231, $f$. 53r.-v. (1303, abril, 29)--, ni tampoco en el segundo ya como procurador de las tierras allende Jijona -ACA, C, reg. 231, f. 56r.-v. (1304, diciembre, 17)-.

48 ACA, C, reg. 231, f. 51r. (1303, abril, 3). LALINDE ABADÍA, J., La Gobernación General..., pp. 38-39 y doc. $\mathrm{n}^{\circ}$ XI. ESTAL GUTIÉRREZ, J.M. del, El reino de Murcia... 1/1, doc. $\mathrm{n}^{\circ} 51$.

49 Es curioso que el sucesor de Montagut, Gombau d'Entença, y el de éste, Juan Jiménez de Urrea, recibiesen de nuevo las segundas apelaciones, pudiendo ejercer sus atribuciones a ambos lados de la línea de Almizra. Cfr. ACA, C, reg. 231, f. 38v. (1305, marzo, 11) y ACA, C, reg. 232, f. 317v. (1309, marzo, 30). FERRER i MALLOL, Mํ.T., Organització i defensa..., doc. $n^{\circ} 46$. CABEZUELO PLIEGO, J.V., Poder público y administración territorial..., I, p. 307 y II, p. 767. 
tes de la Procuración ${ }^{50}$. Si bien, la amplitud de estos verbos no creemos que permita hacerse una idea, ni siquiera remota, acerca de cual sería el área de influencia jurisdiccional de la magistratura en el reino de Murcia. La literatura jurídica tampoco podrá dar luz a esta cuestión, pues a diferencia de lo ocurrido en otros territorios de la Corona de Aragón donde diversos foralistas se interesaron por el oficio, alcanzando a escribir sugestivas páginas sobre su función que en su conjugación de aciertos, errores y omisiones han servido de base a ulteriores investigaciones ${ }^{51}$, lo efímero de la institución en estas tierras hizo que nada de esto ocurriese. Habrá de ser, pues, el Archivo el único soporte semántico de tales voces.

Inmediato a la conquista Jaime II dispuso la compilación de una normativa legal privativa para los murcianos, conocida como Fuero de Murcia, vigente a partir de finales de octubre de $1296^{52}$. Este código, dividido en cuatro libros, se convertía en la columna vertebral de la nueva sociedad murciana al tornarse en rector de las relaciones sociales de sus miembros. En él, lógicamente, aparecian recogidas noticias rela-

50 En 1302 Jaime II comunicaba a diversos municipios del reino de Murcia que todos los asuntos concernientes a la defensa de ese reino los había confiado entre otros, al procurador. ACA, C, reg. 123 , f. 4v. (1302, febrero, 14). Mientras que dos años después, y tras conocer una entrada aragonesa en tierras granadinas protagonizada por Pere de Montagut junto al maestre de la Orden del Temple y al-Abbas ibn Rahu, un marroquí que por entonces se hallaba a su servicio, el rey dirigía al procurador murciano las siguientes palabras: «... circa tuicionem et diligentem custodiam dicti regni nostri Murcie sitis sollicitis... prout de vobis confidimus et speramus". ACA, C, reg. 235, f. 78r. (1304, mayo, 31). Cf. para el reino de Valencia, CABEZUELO PLIEGO, J.V., Poder público y administración territorial..., II, pp. 771-773.

51 Para Valencia, cfr. el Stil de la Governació en diversas ediciones, algunas de ellas comentadas: Furs e Ordinations fetes per los gloriosos reis d'Aragó als regnícoles del Regne de València, Valencia, Imprenta de Lamberto Palmart, 1482, ed. facsímil, Universidad de Valencia, 1977, pp. 519521. FERRÁN SALVADOR, V., Amaldo Juan y su Stil de la Governatio. Transcripción y notas biográficas, Valencia, 1936. LALINDE ABADÍA, J. V., La Gobernación General.., pp. 395-397. CABEZUELO PLIEGO, J.V., Poder público y administración territorial..., II, pp. 718-735. También resultan interesantes la apreciciones realizadas por BELLUGA, P. Speculum Principum, Venecia, 1580. TARAZONA, P. H., Institucions dels furs, y privilegis del regne de Valencia. Eo summari e reportori de aquells, Valencia, 1580. Copia facsímil, Valencia, 1976; y MATHEU SANZ, LI., Tractatus de regimine urbis et regni Valentiae, Valencia, 1654.

Para Aragón resulta de obligada consulta el trabajo de BARDAXI, I. de, Tractatus de officio Gubernationis...

Para Cataluña y las tierras ultrapirenáicas, son de especial interés BOSCH, A., Summari, Index o Epitome dels admirables e nobilissims titols de honor de Cathalunya, Roselló e Cerdanya, Perpignan, 1628. FERRER, M., Recoliectio per me... Doctorem Regii Consilii (ad memoriam tantum et pro faciliore materiae instigationae) facta de casibus in quibus Gubernator Cathaloniae consueverunt et possunt exercere jurisdictionem, Domino Rege et eius Locumtenente generalis absentibus a Cathaloniae, Barcelona, 1647. ALART, B., Privilèges e titres relatifs au franchises, institutions et proprietés communales de Roussillon et de Cerdagne, depuis le XI siècle jusqu'a l'an 1660, Perpignan, 1878.

52 ESTAL GUTIÉRREZ, J.M. del, "El Fuero y las "Constitutiones regni Murcie" de Jaime II de Aragón (1296-1301)", en Anales de la Universidad de Alicante. Historia Medieval, 8, Alicante, 19901991, pp. 19-29. 
tivas a la naturaleza y funcionamiento de las distintas oficialías regnícolas, siendo obviamente la Procuración una de las que sería tratada de forma más prolija en el texto legal. Lo cierto es que tal compilación no ha llegado a nosotros, aunque sí una addenda de 1301 que sobre la base de los furs de València corregía y complementaba el contenido del fuero de 1296. Estas "declaraciones, addiciones, correcciones, substracciones et mutilaciones", como las llamó Jaime II, contemplaron varios items donde se hacía referencia a algunos aspectos de tipo jurídico y procesal en los que el procurador se muestra bien como la autoridad regnícola con competencias exclusivas, o bien con cierto nivel de participación ${ }^{53}$. El documento recoge como competencias privativas del procurador las consideradas como regalías: crimen de lesa majestad, falsa moneda, sellos o cartas reales así como actuación contra oficiales reales. Del mismo modo le facultaba para estar presente en la resolución de pleitos civiles y criminales que correspondiesen a los justicias ciudadanos, e incluso sentenciarlos siempre que se encontrase presente en la villa o lugar, aunque en este caso sus sentencias habrian de ser anotadas en los libros de la Curia del justicia. Quedaban a su arbitrio las causas de viudas, huérfanos y miserables, así como los procesos contra oficiales reales, pasados y presentes. Quedarían asimismo dentro de su jurisdicción el conocimiento y punición de todas las causas de extranjeros, así como las demandas y requisiciones judiciales existentes entre estas personas o de regnícolas hacia ellas; no en el supuesto de que fuesen ellas las que solicitasen justicias contra vecinos, pues en este caso sería el justicia local quien habría de intervenir. Finalmente, el texto legal subraya la cualidad de juez de apelaciones que tiene el procurador cuando se indica que las segundas apelaciones dirigidas al rey, no encontrándose éste en el reino de Murcia, habrían de ser conocidas y sentenciadas por el procurador. En el caso de primera apelación a sentencias del procurador aquélla habría de ser conocida por otro juez para evitar que los habitantes del territorio murciano hubiesen de salir a pleitear a otras partes.

No obstante las atribuciones puestas de manifiesto en este documento, el análisis de las actuaciones concretas permite ampliar de forma considerable su número, al tiempo que matizar ciertas competencias contenidas en el Fuero que serán modificadas a posteriori. A través de ellas podemos elaborar una relación general de temáticas de adscripción privativa o tangencial a la Procuración murciana, muy cercana a la propuesta por nosotros en un trabajo sobre esta magistratura en el reino de Valen$\mathrm{cia}^{54}$, que permiten seguir definiendo al procurador, en palabras de J. Lalinde, como "una mezcla de juez, ejecutor de órdenes regias y jefe de milicias» 55 . De tal forma que su tremenda actividad militar en defensa del territorio encomendado, frente a enemigos exteriores e interiores, descansaba en amplias atribuciones judiciales que le con-

53 ACA, C, reg. 198, ff. 262r.-265r. (1301, febrero, 18). ESTAL GUTIÉRREZ, J.M. del, «EI Fuero y las "Constitutiones...", pp. 29-36 y doc. no 8.

54 CABEZUELO PLIEGO, J.V., Poder público y administración territorial..., II, pp. 776-927.

55 LALINDE ABADÍA, J., La Gobernación General..., p. 76. 
vertían en el magistrado supremo del reino; facultades ambas que difícilmente aparecen disociadas. He aquí la potencia del oficio.

Como jefe militar del reino de Murcia poseía potestad para:

- dirigir la hueste regnícola y disponer aquello que considerase oportuno en defensa del espacio murciano ${ }^{56}$,

- convocar las tropas realengas y de feudatarios ${ }^{57}$.

- embargar bienes de los enemigos y distribuirlos entre los afectos a la causa del rey de Aragón, bien por orden de éste bien de motu proprio ${ }^{58}$, atendiendo a distintos

56 El procurador contaba con una hueste propia a su servicio, no demasiado numerosa, aunque como dice $M^{a}$.T. Ferrer «important perque el formaven homes a cavall de plena dedicació a la professió militar». Si atendemos únicamente a la cifra señalada en la credencial de nombramiento de Pere de Montagut, de abril de 1303, así como a la expuesta en mayo de ese año donde se refería una relación de servidores reales en Murcia, el contingente procuratorial era de diez caballeros, cuatro armados y seis alforrados, con un salario de mil sueldos anuales los primeros y de quinientos los segundos. ACA, C, reg. 231, f. 53r.-v. (1303, abril, 29). ACA, C, reg. 231, ff. 52r.-53r. (1303, mayo, 1). ACA, C, reg. 231, f. 54r. (1303, mayo, 18). FERRER i MALLOL, M‥T., Organització $i$ defensa..., p. 193 y doc. no 28 y 32. Si bien, en fechas anteriores sabemos que tuvo a su servicio a cien hombres, cincuenta caballeros y cincuenta peones, con los que debía proceder a la defensa del territorio murciano y de los intereses reales en él. ACA, C, reg. 197, ff. 98v.-99r. (1300, abril, 1). Cf. FERRER i MALLOL, Mํ.T., Organització $i$ defensa..., pp. 15-55, páginas en las que se derraman constantes alusiones a este asunto.

Era igualmente misión del procurador mantener puntos de vigilancia diurnos y nocturnos, con cargo a los municipios. ACA, C, reg. 120, f. 233r.-v. (1302, enero, 23). Así como un servicio de espionaje interior y exterior. CABEZUELO PLIEGO, J.V., «Reflexiones en torno al oficio...», p. 24.

Por otra parte, existía una conexión militar muy ímportante entre las Procuraciones murciana y valenciana, y no sólo cuando ambas instituciones fueron regidas por una misma persona, el señor de Jérica. A solicitud de la autoridad militar del reino de Murcia las milicias valencianas dirigidas por su procurador habian de colaborar en la defensa de ese espacio. Cf. ACA, C, reg. 108, f. 185r.-v. (1297, julio, 29). Apéndice documental, doc. $n^{\circ}$ 3. ACA, C, reg. 197, f. 99r. (1300, abril, 1). FERRER i MALLOL, Mà.T., Organització $i$ defensa..., p. 17. CABEZUELO PLIEGO, J.V., Poder público y administración territorial..., I, pp. 258-259, 269-270, 278, 280. Tal colaboracionismo procuratorial se mantiene después con respecto a la Procuración de Orihuela. CABEZUELO PLIEGO, J.V., «Precedentes políticos de la Procuración de Orihuela», en Quaderns de Mitjorn, 2, en prensa.

57 Las tropas locales sólo podía convocarlas una vez al año, si bien los procuradores solían saltarse constantemente esta norma, con las consiguientes quejas por parte de los consistorios al rey. $\mathrm{Cf}$. ACA, C, reg. 116, ff. 232r.-233v. ACA, C, reg. 120, f. 234r.-v. (1302, enero, 21). ACA, C, reg. 126, f. 284v. (1303, febrero, 9).

58 En 1301 el procurador quedó con poder para tomar y redistribuir entre fieles a la Corona de Aragón todas aquellas heredades y bienes inmuebles habidos en el reino de Murcia propiedad de peones a quienes les fueron confiscados por ausencia o por rebeldía. La razón de su entrega inmediata era para evitar la despoblación del territorio, pues los agraciados habían de establecer residencia continua en ellos. ACA, C, reg. 198, f. 260r. (1301, febrero, 21). Al año siguiente se dictó una orden para devolver a los sarracenos del lugar de Carchena los bienes que les habían sido tomados por el procurador cuando asaltó y conquistó el lugar por su rebeldía a la soberanía aragonesa. ACA, C, reg. 121, f. 10 r. 
criterios: indemnización por pérdidas ocasionadas por la guerra ${ }^{59}$ o compensación por los servicios prestados ${ }^{60}$,

- recibir el juramento de fidelidad y homenaje feudal de todos los que poseían castillos en nombre del rey. También recibir las plazas para entregarlas a otros alcaides, así como nominar él mismo alcaides ${ }^{61}$,

- supervisar las fortalezas del reino y, caso de resultar necesario, proceder a su abasto y restauración ${ }^{62}, y$

- defender la normativa foral del reino ${ }^{63}$.

Sin perder ese carácter miliciano que infundía respeto y temor entre sus gobernados, el regente de la Procuración contó con importantes atribuciones judiciales que le convertían en juez de apelación y recurso, pudiendo proceder de oficio mediante inquisicions en aquellas causas que eran competencia directa suya ${ }^{64}$. En este terreno, incoaba y resolvía:

- disputas intercomunales por el establecimiento de términos ${ }^{65}$,

- pleitos en los que una de las partes gozaba de la condición de miserabilidad ${ }^{66}$,

- banderías ${ }^{67}$,

59 Sirvan como ejemplo, de los cientos localizados, lo sucedido a Ramon Ferrer, vecino de Alhama, quien había perdido animales por valor de dos mil maravedís castellanos estando en servicio del rey de Aragón. ACA, C, reg. 194, f. 259v. (1296, septiembre, 22). O al caballero Dalmau de Sant Martí, que vio confiscados, como el resto de catalanes residentes en tierra castellana, los bienes que poseía en la ciudad de Sevilla. ACA, C, reg. 194, f. 267v. (1296, octubre, 1).

60 En este punto se valoraba tanto la acción como la calidad social del agraciado. A Sancho Pérez, almogaten que sirvió a Jaime II durante toda la campaña murciana, le fue entregada una heredad cuyas rentas le sirviesen de sustento. ACA, C, reg. 194, f. 259v. (1296, septiembre, 22). Mientras que, por ejemplo, a Pere Jordá habría de entregársele una heredad cuyas rentas no fuesen superiores a seiscientos sueldos anuales. ACA, C, reg. 194, f. 277r. (1296, octubre, 10). La elección del lugar y de la propiedad quedaba al arbitrio del procurador.

61 Sirvan como ejemplos: ACA, C, reg, 197, f. 99v. (1300, abril, 1). ACA, C, reg. 199, f. 86r. (1302, mayo, 31). ACA, C, reg. 201, f. 40v. (1303, febrero, 16). Etc.

62 ACA, C, reg. 198, f. 260r.-v. (1301, febrero, 21). ACA, C, reg. 199, f. 85r. (1302, mayo, 20).

63 Apéndice documental, doc. $\mathrm{n}^{0} 2$.

64 CABEZUELO PLIEGO, J.V., Poder público y administración territorial..., II, p. 771.

65 En agosto de 1296 Jaime Pérez, primer procurador murciano, quedó encargado de verificar los términos de la ciudad de Murcia impuestos en su día por Alfonso el Sabio. ACA, C, reg. 194, $\mathfrak{t}$. 228v. (1296, agosto, 3). FERRER i MALLOL, Mª.T., Organització i defensa..., p. 17. Al año siguiente delimitó perfectamente los términos de la villa de Alicante. ESTAL GUTIÉRREZ, J.M. del, El reino de Murcia bajo Aragón... l/1, doc. nº 143.

66 Cuando en 1303 Jaime II conoce los atropeilos sufridos por Florena Martí, vecina de Guardamar, que se decía persona miserable, a manos de Guillem Paratge, convecino, que se había apropiado de una heredad que reivindicaba la mujer, Jaime II solicita al entonces procurador Bernat de Sarrià que se haga cargo del asunto, "taliter vos habendo in hiis quod predicta mulier, que pauper persona, ut predicitur, et miserabilier est, ius sum consequi valet et habere nec eum duicius opporteat vexari laboribus et expensis set pocius consequì. ACA, C, reg. 118, f. 79r.

67 ACA, C, reg. 108, f. 143v. (1297, julio, 17). 
- delitos contra la Corona: sedición ${ }^{68}$, plagio o collera, defensa de los caminos públicos ${ }^{69}$, herejía, sodomía, falsa moneda y lesa majestad. Al respecto de esta última falta la oligarquía de la capital del reino tenía sus dudas, a finales de 1300 , sobre su vinculación con el oficio de la Procuración, considerando más bien que quedaba dentro de la jurisdicción del justicia civil ${ }^{70}$. La addenda foral de 1301 dejó las cosas en su sitio, tal y como reconocieron esos mismos prohombres en $1303^{71}$.

- etc.

Esos amplísimos poderes convertían a la institución en garante de la cosa pública y de sus gentes. De tal modo que los procuradores podían actuar en labores diplomáticas con personajes, instituciones e incluso con potencias extranjeras que permitiesen acuerdos favorables a los intereses de sus gobernados y por extensión a los reales $^{72}$, procediendo en caso contrario sobre bienes y posesiones de foráneos dentro de su jurisdicción para resarcir pérdidas económicas. Disponían aquellas obras públicas que se consideraban adecuadas para el desarrollo económico de la región, como el trazado de nuevos viales ${ }^{73}$. Procedían igualmente, aunque no de forma privativa, al control de las distintas producciones murcianas en lo relativo a su extracción del territorio, fuese a tierras de la Corona o al extranjero ${ }^{74}$. La Curia de la Procuración tenía, atribuciones sobre el resto de oficiales del reino, además de las procesales aducidas en el Fuero. El baile, por ejemplo, estaba obligado a rendir cuentas ante el procurador del ejercicio de la acción de su oficio, aunque de forma circunstancial ${ }^{75}$. Mientras que los justicias habían de jurar su cargo ante el procurador, hecho que se mantuvo en las

68 El castigo era la expulsión del territorio, como le sucedió a un clérigo de la lglesia de Cartagena. ACA, C, reg. 130, f. 222r. (1303, diciembre, 16). Si bien, en este delito concurría como atenuante el hecho de que los sediciosos fuesen personas pobres y miserables, ya que su condición social y económica, a ojos de la autoridad, no los hacía peligrosos, y como ocurrió con unos vecinos de la ciudad de Murcia se les permitía regresar. ACA, C, reg. 128, f. 135r. (1303, mayo, 15).

$69 \mathrm{El}$ asalto a Pere Andreu, notario de Murcia, en el camino público que comunicaba la capital del reino con Mula -ACA, C, reg. 128, f. 139r-, y el proceso contra Joan Carles, vecino de Orihuela, inculpado de agredir a una mujer en un camino público - ACA, C, reg. 127, f. 284v. (1303, febrero, 9) - fueron llevados por Pere de Montagut, procurador.

70 Apéndice documental, doc. ํㅗ 5 .

71 ACA, C, reg. 129, f. 91r. (1303, septiembre, 16).

72 En 1301 el procurador llevó a efecto una serie de encuentros con un castellano, Gómiz Ferrándiz, con el fin de alcanzar un acuerdo de paz entre Castilla y la Corona de Aragón, que evidentemente puso en conocimiento de Jaime II. ACA, C, reg. 120, f. 142r. (1301, noviembre, 17). En 1304 sucede algo similar, aunque en esta ocasión su interlocutor era granadino. ACA, C, reg. 235, f. 102v. (1304, junio, 29).

73 Así, por ejemplo, en septiembre de 1296 y a solicitud del rey Jaime, disponía que el camino público que transcurría cercano a la población de Callosa lo hiciese por dentro de la villa, obligando a sus viandantes a pasar por él. ACA, C, reg. 194, f. 88r. (1296, septiembre, 10).

74 Como ejemplos véanse: ACA, C, reg. 194, ff. 228v.-229r. (1296, agosto, 3). ACA, C, reg. 121, f. 54r. (1301, junio, 22). ACA, C, reg. 116, f. 311r. (1301, enero, 3). ACA, C, reg. 201, f. 10r. (1303, julio, 7). ACA, C, reg. 129, f. 90r. (1303, septiembre, 16). Etc.

75 ACA, C, reg. 121, f. 79r. (1301, julio, 7). 
tierras dellà Sexona hasta la aplicación a mediados de 1308 de los furs de València, que apuntaban que tal jura se hiciese ante el baile general ${ }^{76}$. Al tiempo que actuar "cum consilio et voluntate procuratoris regni Murcie» cuando juzgasen sobre cosas litigiosas superiores a trescientos sueldos ${ }^{77}$.

Durante la dominación aragonesa de todo el reino de Murcia estas causas fueron campo de actuación ordinaria de la Procuración, así como en los primeros tiempos, después de la sentencia de Torrellas, del espacio denominado ultra Sexonam. No obstante, tras el ingreso de las tierras del norte de ese reino al de Valencia y la aplicación en el mismo del régimen foral valenciano, matizado por los privilegios locales, algunas de esas competencias quedaron en desuso, como el derecho del gobernador a conocer causas correspondientes a los munícipes.

\section{3. "Quod intromettere non debetis». Los límites jurisdiccionales de la Procuración}

Amplias fueron, pues, las competencias de los regentes de la Procuración; la importancia del oficio así lo requería. Pero tal extensión jurisdiccional no alcanzaba el infinito, sino que se veía limitada en atención al resto de poderes que cohabitaban con esta magistratura en el reino de Murcia: territoriales, municipales y señoriales. Lo cierto es que el carácter de representación de la real persona, que el oficio se negaba a abandonar, y la indefinición de sus atribuciones, por inviabilidad manifiesta de reglamentación teórica y por interés de la realeza en que ésta se mantuviese ${ }^{78}$, convirtió al oficio en constante centro de atención por razón de sus constantes altercados jurisdiccionales con otros poderes, que, disfrazados de defensa de sus propias competencias 0 de falsas creencias en proceder en defensa y seguridad de los intereses reales y de la "cosa pública», servían para afianzar su supremacía al tiempo que para obtener, de forma subrepticia e ilegal, ingresos con que sanear las arcas de su oficio, en unos momentos en que comenzaba a ver peligrar su potencialidad jurisdiccional con el trasvase de ciertas competencias privativas hasta esos momentos hacia otras magistraturas ${ }^{79}$.

76 Así se manifestaba en las quejas de Ferrer Descortell, baile general de las tierras oriolanas, referidas a como tras la elección de justicias municipales el día de Navidad en Orihuela y Elche estos oficiales pasaron a jurar sus respectivos cargos al procurador argumentando privilegio antiguo, a pesar de que los fueros de Valencia indicasen que el receptor del juramento había de ser el baile. Este acto, ilegal según la legislación vigente, hacía peligrar los procesos realizados por esos justicias hasta que no prestasen juramento ante el regente de la Bailía, siendo susceptibles de anulación. Tras tener conocimiento de todo, Jaime ll dio validez a tales procesos y ordenó que en adelante fuese el baile quien recibiese de ordinario el juramento de los justicias ciudadanos. Apéndice documental, doc. nº 10 .

77 Tal y como dispone Jaime II al justicia de la ciudad de Murcia. Apéndice documental, doc. ํㅜ 1.

78 OLLA REPETTO, G., Gli ufficiali regi di Sardegna durante il regno di Alfonso IV, Cagliari, 1969, p. 14. PÉREZ GARCÍA, P., «Origen y configuración de una magistratura urbana de la Valencia foral: el Justicia Criminal', en Estudis. Revista de Historia Moderna, 13, Valencia, 1987, p. 44. Id., El Justicia criminal de la ciudad de Valencia (1479-1707), Valencia, 1991. p. 49. CABEZUELO PLIEGO, J.V., Poder público y administración territorial..., pp. 754-755 y 918.

79 CABEZUELO PLIEGO, J.V., Poder público y administración territorial..., II, pp. 928-941. 
Una de las instituciones que más sufrió las injerencias de la Procuración fue la Bailía General, y precisamente a raíz de la pérdida por parte de aquélla de alguna atribución hasta esos instantes privativa, como fue la actuación sobre las minorías religiosas: moros y judíos. Fue durante el gobierno de Jaime de Jérica cuando éste se quejó a Jaime II de haber disminuido su oficio con la concesión de las causas de sarracenos y judíos a la Bailía General ${ }^{80}$. El rey le respondió que tales causas estaban en poder de la Bailía antes de que él accediese a las Procuras valenciana y murciana, en abril de 1298. De ahí en adelante moros y judíos quedaron dentro de la jurisdicción del baile general. Pero ¿y antes? A Jaime de Jérica le antecedió en el gobierno murciano Jaime Pérez y según lo expuesto por el rey al señor de Jérica sería durante el ejercicio del oficio de aquél cuando supuestamente se produciría el cambio. La pregunta sería ¿actuó alguna vez de oficio sobre estas materias Jaime Pérez? En el estado actual de nuestros conocimientos resulta sumamente arriesgado aventurarnos con un pronunciamiento, afirmativo o negativo, por la dificultad que entraña su justificación. Desde luego la temática queda fuera del arco competencial de la Procuración documentalmente en enero de 1298, cuando Jaime II recriminaba al entonces procurador valenciano vizconde de Castellnou su inmiscusión en estas materias por pertenecer al oficio de la Bailía General ${ }^{81}$. Con anterioridad a esa data observamos intervenciones procuratoriales en materia de minorías, aunque todas ellas relativas a la defensa, individual o colectiva, de sus miembros ${ }^{82}$. Sólo una nos llama la atención en cuanto a susceptible de poder desequilibrar la balanza del lado afirmativo, referente a unos moros apresados por Jaime Pérez como procurador murciano, de nombres Abulfaçen y Uxone, acusados de concubinato, y que Jaime II consideró debían quedar libres al no tener que aplicárseles la ley cristiana. La orden de liberación la recibió Jaime de Jérica, ya que el hermanastro del rey de Aragón optó por mantenerlos en prisión $^{83}$. Lo que no somos capaces de precisar es si la actuación del procurador en este asunto derivó de la filiación religiosa de los delincuentes o de la calidad del delito.

Pero lo cierto es que pese a lo dispuesto en las ordenanzas reales al respecto de esta temática, no faltaron injerencias por parte de la Procuración en asuntos de minorías, casi siempre para tratar de hacerse con unos ingresos suplementarios. Hasta tal punto se vulneraba la legalidad que en 1302 Jaime II hubo de reprender fuertemente a los oficiales de la Procuración, titular y lugarteniente, tras conocer como reclamaban las multas y otras penas en que habian incurrido sarracenos murcianos ${ }^{84}$. La rapacidad de los procuradores les llevó a exigir a los justicias ciudadanos presentar ante

80 Apéndice documental, doc. n 3. FERRER i MALLOL. Mª.T., Organització i defensa..., p. 22. CABEZUELO PLIEGO, J.V., Poder público y administración territorial..., II, pp. 800-801 y 811-813.

81 ACA, C, reg. 256, f. 6r.-v. (1298, enero, 22).

82 Sirvan como ejemplos: ACA, C, reg. 194, f. 45r.-v. (1296, agosto, 20-21); f. 74r.-v. (1296, septiembre, 2); f. 81v. (1296, septiembre 4 y 8); f. 104r (1296, septiembre, 22); f. 117v. (1296, septiembre, 29). ACA, C, reg. 105, f. 136r. (1296, octubre, 10). Etc.

83 ACA, C, reg. 110, f. 115v. (1298, abril, 13).

84 ACA, C, reg. 199, f. 33v. (1302, enero, 30). 
ellos las cuentas de la gestión de su oficio en lo relativo a rentas, multas, derechos etc., para poder distraer una parte, cuando igualmente correspondían a la Bailia ${ }^{85}$. Hechos que, desgraciadamente para esta institución, no cesaron de ocurrir, como se pone de manifiesto tanto en la Procuración valenciana como en la oriolana ${ }^{86}$.

Los oficiales municipales, reales y señoriales, también conocieron injerencias de este tipo que igualmente soliviantaban las estructuras del gobierno en el reino de Murcia. En unos casos los poderes del municipio se quejaban de inmiscusiones por parte de la Procuración en competencias privativas de carácter judicial; en otros el asunto iba más allá, pues las quejas se dirigían a la no observancia de los propios privilegios locales ${ }^{87}$. E incluso se alcazaba en la pugna, por parte de los regentes de la Procuración, a la remoción de cargos públicos, destitución recriminada desde la Curia regia cuando no estaba avalada por un mandato real ${ }^{88}$. Algunas de estas actuaciones procuratoriales fueron consideradas injerencia al tiempo que menoscabo real a la autoridad municipal, pues habían sido realizadas dentro de las más absoluta legalidad. Esto ocurrió sobre todo tras la aprobación de la addenda foral de 1301, que en opinión de los prohombres de la capital de reino propiciaba la actuación indiscriminada del procurador en campos hasta entonces vedados a su proceder y pertenecientes al municipio. A mediados de 1303 los murcianos levantaron súplica en este sentido, pues aunque sabedores de las competencias inherentes al oficio de la Procuración protestaban ante el deterioro que sufría la institución del Justiciazgo en razón al constante intervencionismo procuratorial sobre causas que correspondían a los justicias, sobre todo cuando en los procesos aparecían familiares o servidores de la Procuración. EI choque de poderes, y el consecuente mal gobierno, fue atajado por Jaime II en septiembre de ese año cuando, tras explicar que las enmiendas forales de 1301 habían de servir para corregir anacronismos de la ley fundamental de los murcianos, no para potenciar las atribuciones jurisdiccionales de unas instituciones sobre las competencias de las demás, ordenó que los negocios principales que perteneciesen a los justicias fuesen vistos por ellos, no pudiendo intervenir el procurador salvo en legítima

85 Apéndice documental, doc. $\mathrm{n}^{\circ} 6$.

86 CABEZUELO PLIEGO, J.V., Poder público y administración territorial..., II, pp. 935-940.

87 Así se observa en las quejas de municipios como Guardamar, Orihuela, las villas del valle de Elda, Murcia y otros más. Cfr. ACA, C, reg. 116, ff. 233r.-v. (1300, noviembre, 11). ACA, C, reg. 128, f. 171r. (1303, junio, 20). ACA, C, reg. 129, f. 90r.-v. (1303, septiembre, 16). FERRER i MALLOL, M.T., Organització i defensa..., pp. 40-41.

88 Tal sucede en Elche, tras el infructusoso intento por parte de Jaime de Jérica de deponer a Joan Bretón de su oficio de merino. ACA, C, reg. 112, f. 62v. (1298, junio, 22). O cuando Pero López de Rufes, alcaide de la Calahorra, ve peligrar su oficio ante las exigencias de Bernat de Sarrià. ACA, C, reg. 116 , f. 37 v. (1300, agosto, 19$)$.

Sin embargo, en la remoción de los cargos públicos de la villa de Elche por el procurador en septiembre de 1296 no hubo reproche alguno de Jaime II, por haber partido de él la orden. La razón de tal mandato estaba en la negativa de uno de los electos a jurar la soberanía del rey de Aragón. ACA, C, reg. 194, f. 82r. (1296, septiembre, 5). FERRER i MALLOL, Ma.T., Organització i defensa..., p. 17. 
apelación ${ }^{89}$; que entendemos, tal y como se recoge en la legislación valenciana, tras sentencia definitiva otorgada por ese tribunal, o bien por resultar negligente o partidista el instructor principal de la causa ${ }^{90}$.

Curioso resulta el ahínco, en algunos casos exagerado, mostrado por los procuradores por defender los intereses reales sobre cualesquiera otros, si lo extrapolamos a actuaciones de esos mismos oficiales, aunque en calidad de personas privadas, dentro de la más absoluta ilegalidad. Frente a actitudes exacerbadas en el cumplimiento del deber, de las que se derivaba un mal uso del poder, como lo ocurrido en el señorío manuelino del Vinalopó a manos de Jaime Pérez en $1297^{91}$, nos encontramos otras con los mismos protagonistas aunque de signo contrario. Posiblemente el caso más sintomático pueda ser el de Bernat de Sarrià, criticado por sus gobernados por su exceso de celo en la defensa de las regalías, que como feudal vulneraba de forma consciente en interés propio, cuando se inhibió en la negativa de sus vasallos sarracenos habitantes en el término de Orihuela a pagar el cabezaje que de antiguo tenían costumbre salvar los moros oriolanos y que se empleaba para la reparación del castillo $0^{92}$, o bien cuando a finales de 1302 quiso imponer un impuesto sobre la sal en su señorío de Callosa pese a saber que dicha tasa, conocida como gabela de la sal, era prerrogativa real ${ }^{93}$.

\section{LA CURIA DE LA PROCURACIÓN}

Por debajo del procurador se hizo necesaria la presencia de otros oficiales que, con diferentes tareas, hiciesen funcionar la maquinaria política y judicial del Tribunal, tal y como ocurría en el resto de territorios donde operaba la institución.

\section{Lugartenientes}

El origen del lugarteniente procuratorial se encuentra en el exceso de trabajo que recaía sobre su superior así como en la imposibilidad de éste para diligenciarlo. Vin-

89 ACA, C, reg. 129, f. 91r. (1303, septiembre, 16).

90 CABEZUELO PLIEGO, J.V., Poder público y administración territorial..., II, p. 929.

91 A finales de 1297 don Juan Manuel se quejaba a Jaime Il del incumplimiento de los acuerdos de Elche entre ambos, sintiéndose perjudicado por tal. Algunas de las quejas eran producto de malas acciones del entonces procurador murciano Jaime Pérez, quien había tomado la alfarda de la merindad de los moros de Elche, Aspe, Chinorla y Monóvar por un valor anual de tres mil quinientos sueldos así como diversas cantidades de dinero producto de varios asuntos, procedido a la elección de oficiales y otorgado heredades a voluntad. ACA, C, reg. 106, ff. 93v.-94v. (1297, noviembre, 22). GIMÉNEZ SOLER, A., Don Juan Manuel. Biografía y estudio crítico, Zaragoza, 1932, doc. ํo XII. ESTAL GUTIÉRREZ, J.M. del, El reino de Murcia bajo Aragón... $/ 1 /$, doc. $n^{0} 151$. FERRER i MALLOL. Ma.T., Organització i defensa..., p. 18.

92 ACA, C, reg. 120 , f. 234r. (1302, enero, 19).

93 Que hubo de revocar tras mandato real de 6 de enero del año siguiente. ACA, C, reg. 126, f. $209 \mathrm{v}$. 
culado a los oficios de alta responsabilidad, como apuntan García de Valdeavellano ${ }^{94}$ - García Marín ${ }^{95}$, las funciones de los lugartenientes eran las mismas que las de sus superiores, desarrolladas, en el caso murciano, sobre el mismo espacio jurisdiccional que los procuradores.

La Procuración del reino de Murcia contó con un único lugarteniente, atendiendo a que el territorio no era demasiado extenso para ser dividido en Lugartenencias, como ocurriese en Valencia. Es posible que naciese de la mano de la magistratura, como sucede con su homólogo de la Bailía ${ }^{96}$, aunque no tenemos noticia alguna de su existencia durante prácticamente el primer año. Las primeras referencias a la Lugartenencia procuratorial murciana las hallamos en la primavera de 1297, cuando en diversos documentos Jaime II se dirige al «nobili et dilecto nostro Jacobo Petri, fratri suo, procuratori regni Murcie, vel eius locumtenentim ${ }^{97}$. A partir de estas fechas las noticias al oficio son habituales. El primer personaje del que conocemos nombre es Joan de Vidaure, que ejerce como lugarteniente durante el gobierno de Jaime de Jérica. Localizamos a Vidaure en calidad de tal ya en fecha tardía, 1300, actuando junto a Bernat de Sarrià, entonces consejero real, y Domingo de Biscarra para tratar de atraer del lado de Jaime II a Pedro Jiménez de Lorca ${ }^{98}$, así como en otras causas ${ }^{99}$. Un año después documentamos regentando ese oficio a Guillem de Vilaragut, ya con Bernat de Sarrià al frente de la magistratura ${ }^{100}$. Vilaragut aparece en el reino de Murcia en los primeros instantes de la conquista ${ }^{101}$, obteniendo en febrero de 1301 la alcaidía de la fortaleza oriolana ${ }^{102}$, que simultaneó con la Lugartenencia hasta su muerte, ocurrida a

94 GARCÍA DE VALDEVELLANO, L., Curso de Historia de las Instituciones Españolas. De los origenes al final de la Edad Media, Madrid, 1970, p. 496.

95 GARCÍA MARÍN, J. M. ${ }^{a}$, El oficio público en Castilla durante la Baja Edad Media, Sevilla, 1974, p. 54 y nota $n^{\text {o }} 103$.

96 ESTAL GUTIÉRREZ, J.M. del, El reino de Murcia bajo Aragón... 1/1, doc. ํำ 112. (1296, junio, 29).

97 En mayo de 1297 Jaime II se dirige al procurador murciano o a su lugarteniente para comunicarles que en caso de que los vecinos de varias poblaciones - Alcantarilla, Molina, etc.- negasen el homenaje de fidelidad al abad del monasterio cisterciense que se iba a construir en ese reino, procediesen contra ellos confiscando sus bienes para obligarles a realizar dicho acto de reconocimiento. ACA, C, reg. 108, f. 34v. (1297, mayo, 21). Acerca de esta fundación cisterciense cf. SÁlNZ DE LA MAZA LASOLI, R., «El monasterio cisterciense del Real de Murcia. Un proyecto fracasado de Jaime II», en Anales de la Universidad de Alicante. Historia Medieval, 9, pp. 179-196

98 A quien caso de aceptar la oferta se le concedería a perpetuidad el lugar de Beniscorna, en el reino de Murcia. ACA, C, reg. 197, f. 73r. (1300, febrero, 17).

99 FERRER i MALLOL, M‥T., Organització i defensa..., p. 23.

100 ACA, C, reg. 198, f. 251r. (1301, febrero, 1). ESTAL GUTIÉRREZ, J.M. del. El reino de Murcia bajo Aragón... V1/ doc. no 124. ACA, C, reg. 198, f. 254r.-v. (1301, febrero, 18). ACA, C, reg. 118, f. 19r. (1301, febrero, 20). ACA, C, reg. 120, f. 258v. (1302, enero, 28). FERRER i MALLOL, Ma .T., Organització i defensa..., p. 47.

101 FERRER i MALLOL, Ma.T., Organització i defensa..., p. 15.

102 ACA, C, reg. 198, f. 254r.-v. (1301, febrero, 18). FERRER i MALLOL, Mª.T., «La tinença a costum d'Espanya...», pp. 16 y 47. 
mediados del año siguiente ${ }^{103}$. El último personaje que localizamos al frente de este oficio es Berenguer de Puigmoltó, caballero con una gran vinculación con el reino de Murcia $^{104}$ y posteriormente con el territorio de él segregado tras la sentencia de Torrellas, en el que también llegó a ser lugarteniente procuratorial ${ }^{105}$. Su relación con el oficio sólo la constatamos en un documento fechado en mayo de 1303, en el que se refiere a una sentencia dictada «per Berengarium de Podio Moltone, tunc tenentem locum procuratoris dicti regni ${ }^{106}$, desconociendo si en esos momentos todavía desempeñaba el cargo, aunque sí continuaba al servicio del rey, en nombre de quien poseía dos caballos armados y otros dos alforrados para la defensa del reino de Murcia ${ }^{107}$. Un tiempo después quedó como alcaide de Alhama ${ }^{108}$.

\section{El asesor}

Las prerrogativas judiciales de la magistratura, unidas al-desconocimiento de sus titulares de la ciencia jurídica, hicieron necesaria la presencia de un profesional del Derecho, abogado o doctor, que aconsejase al procurador en esta materia a fin de que no se incurriese en ilegalidad en los procesos incoados y sentenciados en ese Tribunal. Hasta tal punto se convierte en imprescindible su concurso que sin él cualquier causa o proceso realizado en la Curia de la Procuración quedaba anulado por defecto de forma. Su misión fundamental era conocer, y en algún caso sentenciar, las causas que fuesen presentadas ante el Tribunal de la Procuración o bien aquéllas otras que iniciara el procurador en nombre del rey ${ }^{109}$.

En cuanto a sus titulares, nombrados siempre por el rey en atención a la importancia del oficio, diremos que la brevedad del gobierno aragonés en el reino de Murcia

103 ACA, C, reg. 199, f. 88r. (1302, junio, 13). FERRER i MALLOL, M‥T., "La tinença a costum d’Espanya...", docs, no 2 y 3 .

104 Apareció, junto a otros muchos caballeros, entre la tropa que entró en el reino de Murcia en 1296 y pronto obtuvo favores reales por su arrojo. Alcanzó el justiciazgo alicantino, la merindad de la villa de Elche y posteriormente la alcaidía del castillo de Orihuela. Así como también diversas posesiones territoriales en el reino de Murcia. ACA, C, reg. 108, f. 143v. (1297, julio, 17). ACA, C, reg. 112, f. 267v. (1298, junio, 22). ACA, C, reg. 198, f. 267r. (1301, febrero, 25). ACA, C, reg. 199, f. 86r. (1302, mayo, 31). FERRER i MALLOL, Ma.T., Organització i defensa..., pp. 64-65. Id., "La tinença a costum d'Espanya...", p. 47.

105 Cf. FERRER i MALLOL, M‥,., Organització i defensa..., pp. 63-72.

106 ACA, C, reg. 128, f. 139r. (1303, mayo, 18).

107 ACA, C, reg. 231, f. 54r. (1303, mayo, 18). FERRER i MALLOL, Mª.T., Organització i defensa..., doc. $\mathrm{n}^{\mathrm{0}} 32$.

108 ACA, C, reg. 201, f. 96v. (1304, febrero, 1). FERRER i MALLOL, Mํ.T., Organització i defensa..., p. 65.

109 Cf. ALANYA, L. (ed.), Aureum opus regalium privilegiorum civitatis et regni Valentie cum historia cristianisimi regis Jacobi ipsius primi conquistatoris, Valencia, 1515, reimpresión facsímil Valencia, 1972, con índices preparados por CABANES PECOURT, M.D., f. 77v. BARDAXI, I. de, Tractatus de officio Gubernationis..., 2, pp. 170-171, 173-175. FERRER i MALLOL, Mํ. .T., Organització i defensa..., p. 148. CABEZUELO PLIEGO, J.V., Poder público y administración territorial..., II, pp. 963-995. 
hizo que fueran escasamente media docena los letrados que ocuparon el cargo, removidos en cada ocasión que cambiaba el titular de la magistratura. El primero que conocemos en el oficio es García Munyoz, nominado asesor de la institución que entonces regía Jaime Pérez el 21 de agosto de 1296, habiendo sido con anterioridad juez de la Curia regia, por lo que le suponemos hombre de gran prestigio en el campo de las leyes ${ }^{110}$. Quizá ejerciese el oficio hasta primeros de 1298 , pero no más allá, pues cuando Jaime de Jérica unifica en sus manos las Procuraciones de Valencia y Murcia es otro juez real, Guillem de Jàfer, quien se hace con él, en concreto el 1 de mayo, apareciendo como «assessoris Procuracionis regnorum Valencie et Murcie»11. Si bien, es posible que durante el gobierno del señor de Jérica existiesen dos Asesorías atendiendo a que eran dos las magistraturas que regía, una en cada reino. Esto es así porque con fecha de julio de 1300, cuando al frente de la Procuración murciana se encuentra Bernat de Sarrià, éste recibe una orden de Jaime II para salvar a Joan de Meyà el salario adeudado durante los dos años que ocupó el cargo de asesor de Jaime de Jérica, a razón de mil sueldos anuales. El hecho de que Meyà hubiese colaborado con Jaime de Jérica, de que percibiese el dinero en moneda murciana, no valenciana ${ }^{112}$, y de que fuese uno de los compiladores de los fueros murcianos ${ }^{113}$, nos hace pensar en la idea de la doble Asesoría, por otra parte lógica al pensar que la prestación de servicios, por razones de presencia física, en un solo Tribunal había de colapsar necesariamente el otro, ante la imposibilidad legal de poder sacar causas fuera de los reinos y la no existencia de huellas de lugartenientes del asesor.

Tras la destitución del señor de Jérica se regresa al sistema de gobierno unipersonal y uniterritorial, y así al tiempo que el vizconde de Castellnou se hace con la Procura valenciana, Bernat de Sarrià ocupa la murciana. Veintidós días después del nombramiento de Sarrià encontramos en la Asesoría a Bernat Benet ${ }^{114}$, que se mantuvo más de tres años en el desempeño del cargo hasta ser sustituido por otro letrado, Nicolau Porcel, en mayo de 1303, quien como su antecesor obtenía el oficio de "iudicatus seu assessor Procuracionis regni Murcie» a beneplácito, con un salario anual de mil quinientos sueldos valencianos - superior al obtenido por Meyà-sobre las rentas del reino, habiéndole de ser abonado por el baile general ${ }^{115}$. Días antes había sido nominado procurador Pere de Montagut. Porcel fue reprendido fuertemente por Jaime II en septiembre de ese año al conocer que, no contento con el salario que percibía, extorsionaba a quienes acudían al Tribunal de la Procuración exigiendo a cada una de las partes en litigio seis dineros por libra, lo que iba claramente contra fueros, usos y costumbres de los murcianos, ya que la percepción de su salario ordinario le vedaba

110 ACA, C, reg. 194, f. 243r. FERRER i MALLOL, M‥T., Organització $i$ defensa..., p. 148.

111 ACA, C, reg. 196, f. 212r.-v. FERRER i MALLOL, M‥T., Organització i defensa..., p. 148.

112 CABEZUELO PLIEGO, J.V., Poder público y administración territorial..., Il, pp. 976 y 988.

113 ESTAL GUTIÉRREZ, J.M. del, El reino de Murcia bajo Aragón... l/1, docs. no 114 y 148. ld., «El fuero y las "Constitutiones...», pp. 25-27.

114 ACA, C, reg. 197, f. 110r.

115 ACA, C, reg. 231, f. 53v. (1303, mayo, 17). FERRER i MALLOL, Mª.T., Organització $i$ defensa.., pp. 148-149. 
tomar numerario por el desempeño de su oficio ${ }^{116}$. No sabemos si por este hecho, por otro lado desgraciadamente habitual y que revela las dificultades para la percepción del salario ${ }^{117}$, o por otra razón que desconocemos, Nicolau Porcel fue depuesto de la Asesoría, entregada en diciembre de ese año a Guillem Mir, letrado de la capital del reino, con los mismos derechos aunque con un salario sensiblemente inferior, mil sueldos anuales ${ }^{118}$, quien ya en enero del año siguiente se quejaba de la dificultades en la recepción del monto salarial así como de otros derechos que habían de llegar a sus manos por razón de su oficio' ${ }^{19}$.

Tras la sentencia de Torrellas de agosto de 1304 y la división del reino de Murcia en dos mitades, Guillem Mir continuó ejerciendo sus funciones como asesor en la mitad norte, en la Procuración ultra Sexonam, con capital en Orihuela, aunque con un salario reducido en un cincuenta por ciento ${ }^{120}$.

\section{El escribano}

La misión principal del escribano era la de realizar todas las actas, cartas o escrituras concernientes al oficio de la Procuración, así como proceder a su custodia junto con la del sello de la magistratura' ${ }^{121}$. Posiblemente, como ocurría en el reino de Valencia, hubiera de asistir al procurador cuando éste se decantaba por pactar composiciones económicas con los delincuentes para así anotar la cantidad obtenida por esa vía en los libros de la Escribanía ${ }^{122}$.

Conocemos bien poco del oficio y de sus titulares durante el gobierno aragonés de Murcia. Si trasladamos a la Escribanía procuratorial una orden real dirigida a los munícipes murcianos pocos meses después de la conquista, todos los documentos y cartas públicas habían de ser redactadas en «vulgar, per la part que les gens pus clarament o entenen ${ }^{123}$. En cuanto a quiénes la desempeñaron, sabemos que tras acceder a la Procuración Jaime de Jérica, pretendió sustituir a los escribanos de las Curias de Valencia y de Murcia, a lo que Jaime II se negó en razón a que éstos, que habían obtenido el cargo con anterioridad a la presencia en el oficio del señor de Jérica, prestaban un buen servicio en él ${ }^{124}$. No tenemos ninguna credencial de nombramiento

116 ACA, C, reg. 129, f. 90v. (1303, septiembre, 16).

117 CABEZUELO PLIEGO, J.V., Poder público y administración territorial..., ll, pp. 979-982.

118 Apéndice documental, doc. nำ.

119 ACA, C, reg. 131, f. 56v. (1304, enero, 8).

120 Que le fue incrementado con un ingreso extraordinario de doscientos sueldos para «auxilium expensarum domus vestre" sobre las multas y otros derechos del justicia oriolano. ACA, C, reg. 231, f. 56v. (1304, diciembre, 5). ACA, C, reg. 231, f. 59v. (1308, agosto, 26). FERRER i MALLOL, $M^{2}$. T, Organització $i$ defensa..., p. 149.

121 FERRER i MALLOL, M‥T., Organització i defensa.., p. 151. CABEZUELO PLIEGO, J.V., Poder público y administración territorial..., II, pp. 996-999.

122 CABEZUELO PLIEGO, J.V., Poder público y administración territorial..., II, p. 999-1000.

123 ESTAL GUTIÉRREZ, J.M. del, El reino de Murcia bajo Aragón... V/1, doc. n 141. (1296, agosto, 29$)$.

124 Apéndice documental, doc. $n^{\circ} 3$. 
de escribano de la Procuración entre 1296 y 1304, pero sí indicios de personas que ejercieron como tal. Uno de ellos es Pere Ça Muntcada, de quien Jaime II apunta en junio de 1302 que es «scriptor dilecti consiliarii nostri Bernardi de Sarriano, procuratoris regni Murcie» ${ }^{125}$. Otro sería Pere Andreu, un notario de la ciudad de Murcia, que según refería el rey a Pere de Montagut había estado a las órdenes de su antecesor en el cargo, Bernat de Sarrià, quien le envió al asedio del castillo de Mula para redactar los documentos necesarios sobre los pactos habidos entre Sarrià y los comendadores santiaguistas, sufriendo en su viaje un ataque y heridas de azagaya ${ }^{126}$.

\section{Otros cargos}

Junto a asesor y escribano, oficios de carácter técnico para los que se requería una cierta cualificación profesional, el Tribunal de la Procuración contó con otros cargos de tipo ejecutivo, dado que su misión principal era poner en práctica las órdenes que les dictasen sus superiores. Se trata de porteros, correos, alguaciles, corredores... Sólo tenemos noticia de uno estos oficiales, y muy tardía; se trata del nombramiento en febrero de 1304 de Arnau de Milleres como alguacil de la Procuración murciana de por vida ${ }^{127}$, cuando a ésta escasamente le restaba seis meses de existencia.

125 ACA, C, reg. 124, f. 188r.-v. (1302, junio, 8).

126 ACA,$C$, reg. 128 , f. 138r. Debe tratarse del mismo Pere Andreu a quien Jaime II concedió durante el asedio al castillo de Orihuela una serie de posesiones en la ciudad y huerta de Murcia a perpetuidad por su fidelidad a la causa del rey de Aragón. ACA, C, reg. 194, f. 247v. (1296, mayo, 10).

127 Apéndice documental, doc. № 9. FERRER i MALLOL, Mª .T., Organització i defensa..., p. 152. 


\section{APÉNDICE DOCUMENTAL ${ }^{128}$}

1296, agosto, 3. Valencia.

Jaime /l dispone que el justicia de la ciudad de Murcia pueda juzgar hasta trescientos sueldos. Cuando la cosa litigiosa supere ese valor sólo lo podrá hacer con la aquiescencia del procurador del reino.

ACA, C, reg. 194, f. $227 \mathrm{v}$.

\section{Civitatis Murcie M $^{129}$}

Noverint universi quod nos, Jacobus, Dei gracia rex Aragonum, Maioricarum, Valencie et Murcie ac comes Barchinone, volumus, concedimus et ordinamus quod iusticia civitatis Murcie possit super penis pecuniariis et caloniis per quaslibet personas dicto iusticie racione dicti officii dandis et solvendis qualibet racione ascendentibus ad summam trescentorum solidorum regalium et infra moderari et inde remissionem moderare facere ante sentenciam et post prout ei racionabiliter videbitur faciendum. Super caloniis vero ascendentibus ultra summam trescentorum solidorum dicte monete cuiuscumque fuerit quantitatis possit dictus iusticia moderari et remissionem inde moderare facere racionabiliter cum consilio et voluntate procuratoris regni Murcie, sine cuius consilio et voluntate ultra dictam quantitatem trescentorum solidorum moderari seu remissionem aliquam facere non presumat. Nos enim moderacionem et remissionem quam dictus iusticia per se de caloniis et penis predictis ascendentibus ad summam trescentorum solidorum et infra et cum consilio et voluntate dicti procuratoris de caloniis et penis ascendentibus ultra dictam summam trescentorum solidorum fecerit, ut est dictum, obtinere volumus robur perpetue firmitatis. Mandantes procuratoribus, iusticiis, baiulis et universis aliis officialibus et subditis nostris, presentibus et futuris, quod presentem concessionem et ordinacionem nostram firmam habeant et observent et non contraveniant nec aliquem contravenire permittant aliqua racione. Predictam autem concessionem et ordinacionem durare solummodo volumus et valere dum de nostre fuerit beneplacito voluntatis.

Data Murcie, IIIำ nonas augusti, anno Domini $M^{\circ} C^{\circ} C^{\circ} X^{\circ}$ sexto.

128 Agradezco a la Dra. Regina Sáinz de la Maza, del Consejo Superior de Investigaciones Científicas, la revisión de este apéndice documental y sus acertadas puntualizaciones paleográficas.

129 Letra no contemporánea. 
1297, julio, 27. Lérida.

Jaime Il ordena a Jaime Pérez, procurador del reino de Murcia, que obligue a las autoridades municipales de la villa de Orihuela a aceptar como norma legal el Fuero de Murcia.

$A C A, C$, reg. 108 , f. 171 r.

Jacobus, et cetera, viro nobili et dilecto Jacobo Petri, fratri et procuratori regni Murcie, salutem et dileccionem. Cum nos ad communem et utilem statum tocius regni Murcie foros generales et communes toti regno provide et cum magna deliberacione ad proborum hominum instanciam civitatis et regni predicti duxerimus statuendos, ad quorum observacionem omnes habitantes in regno predicto tenentur eciam obligantur, qui fori iam tam in civitate quam in aliis locis regni ipsius ab hominibus observantur, exceptis probis hominibus Oriole, qui eos, ut intelleximus, renuunt observare. Et non sicut pars conveniens immo turpis que suo non congruit universo, idcirco vobis dicimus et mandamus firmiter et dictricte quatenus homines loci predicti de Oriola ad observacionem ipsorum fororum modis quibus peteritis compellatis.

Data llerde, $\mathrm{VI}^{\circ}$ kalendas augusti, anno Domini $\mathrm{M}^{\circ} \mathrm{CC}^{\circ} \mathrm{XC}^{\circ}$ septimo.

Petrus Marchi.

\section{3}

1299, junio, 10. Nápoles.

Jaime II acusa recibo a Jaime de Jérica, procurador de los reinos de Valencia y de Murcia, de las distintas cartas de él recibidas y le contesta a ciertos interrogantes expresados en ellas acerca del oficio de la Procuración.

ACA, C, reg. 113, ff. 164v.-165r.

Jacobus, et cetera, viro nobili et dilecto Jacobo, domino de Xerica, procuratori regnorum Valencie et Murcie, et cetera. Receptis litteris vestris nuper nobis transmissis et hiis que continebantur in eis plenarie intellectis, sic vobis duximus respondendum quod placuit nobis multum de significata nobis in eis tranquillitate et statu pacifico regnorum Valencie et Murcie et vestram preterea diligenciam comandamus. Ad id autem quod nobis per ipsas vestras litteras intimastis quod cum hoc anno induxissetis exercitum hominibus regni Valencie ut sequerentur vos ad dampnificandum et offendendum hostes nostros dum in regnum Murcie accederetis et quod illi de civitate excusarunt se ex indultis eis privilegis quod non tenebantur ire in exercitum nisi nobiscum insimul et illi de regno dixerunt se facturos sicuti illi de civitate, respondemus vobis quod si illi de civitate ex predictis eis indultis privilegiis possunt se racionabiliter excusare de non eundo in exercitum nisi tantum nobiscum gravamur, tamen et displicet nobis si alii de 
regno quos non credimus ex privilegiis vel alia iusta causa posse racionabiliter excusari ab ipso exercitu faciendo non fuerunt vos secuti in exercitum supradictum et eos proptera debite corrigemus loco et tempore opportunis. Ad alia vero que nobis per ipsas literas scripssistis nos subtraxisse comisso vobis officio procuratoris sarracenos et iudeos, custodiam rerum prohibitarum et ea comisisse baiulis nostris generalibus dictorum regnorum tam in civili quam criminali noveritis quod antequam vobis dictum procuratoris comisissemus officium, predictam custodiam sarracenos et iudeos tanquam ad officia dictarum Baiuliarum spectancia mandaveramus per eosdem baiulos cum baiulis eisdem insimul procurari. Cum intencionis nostre non fuerit nec est subtrahere seu diminuere aliqua de dictis officiis que noscantur ad ea racionabiliter pertinere, verumtamen nos dante Domino intendimus esse in brevi in partibus ipsis et tunc certificari plenius ad que officiorum ipsorum predicta spectare noscantur super eis deliberabimus quod fuerit racionis. Ad alia autem que de Scribaniis Procuracionum ipsarum nobis scripsistis, respodemus vobis quod cum nos antequam predicta Procuracionum officia vobis comissa fuissent, Scribanias ipsas quibusdam benemeritis duxerimus concedendas eas a manibus eorum revocari non expedit dum bene et legaliter se habeant in eisdem. Ad alia vero que super mitenda illuc peccunia pro negociis et serviciis nostris nobis per predictas vestras litteras scripssistis, respondemus vobis quod cum dominus Papa non satisfecerit nobis de quantitate peccunie in qua nobis tenebatur pro prosecucione negocii Sicilie quod habuimus, nullam illuc ad presens mitere possumus peccunie quantitatem set in antea curabimus ad partes ipsas transmitere // illam quam poterimus peccunie quantitatem. Ad ea vero que super emendis equorum et aliorum animalium illorum de comitiva vestra nobis per ipsas vestras literas scripsistis, quia certum est nobis baiulos nostros regnorum ipsorum nullam de iuribus et proventibus officiorum Baiuliarum ipsarum recipere peccunie quantitatem propter plures et diversas asignaciones factas per nos diversis personis in iuribus et proventibus ipsis eis ad presens super hiis non scribimus, set cum nos in partibus nostris presentes fuerimus quod, ut predicitur, dante Domino erit in brevi, sit circa emendam equorum et aliorum animalium predictorum providere curabimus quod vos et illi de familia vestra contentos vos poteritis reputare, petitas autem literas ad fratrem Romeum, de Ordine Minorum, et alios manumissores illustris infantis dopni Petri, bone memorie fratris nostri, super prorrogacione solucionis facienda de precio castrorum dicti fratris nostri per ammiratum emptorum, licet alias iam super hoc eis scripsserimus vobis ad presens per portitorem presencium destinamus. Ad ea autem que alie vestre litere continebant super facto Ferdinandi, fratris nostri, respondemus vobis quod providimus supersederi in negocio ipso in negocio ipso (sic) usque quo nos simus in partibus ipsis presentes et tunc super ipso negocio vobiscum confferre intendimus et facere quod nobis decencius visum fuerit expedire. Circa vero statum pacificum et tranquillum regnorum nostrorum vestro regimine comissorum sic prudenter et sollicite intendatis quod fideles nostri sub vestro bono regimine in statu gaudeant pacifico et tranquillo vosque possitis proptera nobis occurrere merito comendandus. Et ut in columitate et statu persone nostre quem audire prosperum perebtatis, valeatis plenius informari. Scire vos volumus quod per Dei graciam plenam fruimur corporis sospitant.

Data Neapoli, IIII- idus iunii, anno Domini $\mathrm{M}^{\circ} \mathrm{CC}^{\circ} \mathrm{XC}^{\circ}$ nono. 
[1300, abril, 1. Barcelona].

Jaime Il pone al servicio de Bernat de Sarrià, procurador del reino de Murcia, a cincuenta caballeros y cincuenta peones para la defensa del territorio murciano además de la hueste que ya reside en él.

ACA, C, reg. 197, f. $98 \mathrm{v}$

\section{Eiusdem $^{130}$}

Jacobus, et cetera, dilecto consiliario suo Bernardo de Serriano, procuratori regni Murcie, salutem et cetera. Cum ultra illam equitum et peditum comitivam que ad stipendia nostra in regno Murcie moratur ad presens pro tuiciori et fortiori deffensione dicti regni Murcie quinquaginta equites et quinquaginta pedites per vos in dicto regno ad servicium nostrum retinere providimus et velimus, ideo dicimus et mandamus vobis quatenus dictos quinquaginta equites et quinquaginta pedites sub stipendiis sive solidis Curie nostre in nostrum servicium teneatis in regno predicto. Nos enim volumus et concedimus per presentes quod cuilibet equiti tenenti equm armatum cum tribus equitaturis ultra lipsum/ equm armatum dentur et solvantur octo solidos regalium Valencie pro unoquoque die, et cuilibet tenenti equm alforratum cum duabus equitaturis ultra ipsum equm alforratum dentur et solvantur sex solidos pro die, et cuilibet peditum predictorum octo denarii eiusdem monete. Verum, si dictus eques tenens equm armatum non haberet nisi tres equitaturas, dentur eidem sex solidos tamen monete predicte et sic descensive secundum quod tenebit equitaturas. Et si ille qui equm alforratum tenuerit non habuerit nisi duas equitaturas, dentur sibi quatuor solidos tamen monete iamdicte, et sic descensive secundum quod tenebit equitaturas.

Data ut supra. [Barchinone, kalendas aprilis, anno Domini $\mathrm{M}^{\circ} \mathrm{CCC}^{\circ}$ ]. Idem.

\section{5}

1300, noviembre, 11. Valencia.

Jaime Il ordena a Bernat de Sarrià, procurador del reino de Murcia, sobreseer ciertos procesos y esperar hasta que él acudiese a ese territorio tras haber recibido una queja de las autoridades municipales murcianas en el sentido de que actuaba contra fueros y privilegios de la ciudad y reino.

$A C A, C$, reg. 116, f. 232r.

130 Letra no contemporánea. 
Bernardo de Serriano, procuratori regni Murcie, et cetera. Constituti ante nostram presenciam nuncii seu procuratores universitatis civitatis Murcie nobis exposuerunt conquerendo quod vos gravatis eosdem contra forum et racionem et etiam contra privilegia sua et observancia eorumdem super hiis casibus, videlicet qui sequntur. Primo quod compellitis quosdam homines civitatis Murcie qui sunt super facto criminis lese maiestatis, ut dicitur, accusati, ad respondendum coram vobis super eo cum non teneantur respondere in casu predicto ni coram iusticia civitatis Murcie. Secundario quod capitis seu capi facitis in dicta civitate aliquos homines extraneos qui sunt de quibusdam maleficiis seu excessibus accusati, cum iuxta forum et privilegia dicte civitati concessa non teneantur nec coram eiusdem iusticia respondere. Tercio quod facitis cognosci de secundariis appellacionibus cum iuxta forum predictum, nisi per nos personaliter cognosci, non debeat de eisdem. Quarto quod cum ipsi iuxta eorum privilegia non teneantur servire cum equis armatis pro hereditamentis que diversa fuerunt pro cavalleriis, compellitis ipsos ad serviendum cum equis armatis pro hereditamentis superius nominatis. Quinto quod cum ipsi non teneantur iuxta eorum privilegia facere exercitum, nisi semel in anno, compellitis ipsos ad faciendum dictum exercitum contra privilegia supradicta. Sexto quod sarraceni qui consueverunt morari in la Rexaca et in alqueriis orte regni Murcie habent deserere ipsa loca et inde affugere propter multas oppressiones et gravamina que inferris seu inferri facitis eisdem. Quare vobis dicimus et mandamus quatenus super predictis et quolibet predictorum supersedeatis procedere ac procedi facere donec nos fuerimus in regno Murcie personaliter constituti, et siquam pignora ab eis tenetis seu capi fecistis racione predicta ea incontinenti restituatis eisdem ac restitui faciatis.

Data ut supra. [Valencie, III idus novembris, anno Domini $\mathrm{M}^{\circ}$ trecentesimo]. Idem.

1302, enero, 30. Valencia.

Jaime Il ordena a Bernat de Sarrià, procurador del reino de Murcia, no inmiscuirse en la jurisdicción ordinaria del baile general del territorio.

ACA, C, reg. 199, ff. 33v.-34r.

Dilecto consiliario suo Bernardo de Serriano, procuratori regni Murcie, vel eius locumtenenti ac alii cuicumque procuratori qui pro tempore fuerit, salutem et dileccionem. Cum ad officium baiuli nostri regni Murcie specialiter pertineat audire // compotum a iusticiis civitatis et aliorum locorum regni predicti de omnibus redditibus, caloniis et proventibus ac iuribus iusticiarum locorum predictorum ac exigere et recipere nomine nostro quicquid ex ipsis iuribus remanet solvere salariis iusticiarum et assessorum, et vos, ut intelleximus, intromitatis vos de premissis. Ideo vobis dicimus et mandamus quatenus de hiis vos ulterius nullatenus intromitatis sed hec expediri permitatis percipi et haberi per baiulum antedictum. Nos enim per presentem mandamus iusticiis dicti 
regni, presentibus et qui pro tempore fuerint, ut cum dicto baiulo computent et ipsi baiulo et non vobis nec altri cuicumque respondeant et satisfaciant de premissis.

Data Valencie, IIIIo kalendas febroarii, anno quo supra. [millesimo CCCํㅜ primo] Bernardus de Aversone, mandato domini episcopi.

\section{7}

1303, septiembre, 16. Caspe.

Jaime Il concede a Pere de Montagut, procurador del reino de Valencia, el castillo de Molina y le ordena que traslade su residencia a él.

ACA, C, reg. 201, f. 40v.

Jacobus, et cetera, dilecto suo Petro de Monteacuto, procuratori regni Murcie, salutem et cetera. Significamus vobis quod Eymericus de Bellovicino, procuratori nomine dilecti consiliarii nostri Bernardi de Serriano, reddit nobis verbo castrum de Molina, quod memoratus Bernardus tenebat pro nobis. Nosque sicut providimus et ordinamus quod castrum predictum de Molina tradatur vobis nomine nostro, eapropter vobis dicimus et mandamus quatenus dictum castrum de Molina \recipiatis/ et, cum ipsum realiter et potenter receperitis, nos de reddicione ipsius castri habebimus pro contentis ac prefato Bernardo inde quitium appellamus. Quod castrum, cum receperitis illud diligenter teneatis et custodiatis aut teneri et custodiri diligenter faciatis, prout melius ad servicium nostrum videbitis expedire, preterea nos de retinencia dicti castri vobis, prout oportunum fuerit, curabimus providere. Quicquid autem circa hec faceritis nobis continuo intimare curetis preterea placeret nobis et teneremus pro bono quod ex quo receperitis dictum castrum in et vestrum domicilium transferatis ac in eodem meiorem residenciam faceritis ut ipse locus melioramentum inde reciperet et diligencius custodiretur.

Data in loco de Casp, XVI” kalendas octobris, anno quo supra.

Bernardus de Aversone, mandato regio.

\section{8}

1303, diciembre, 17. Valencia.

Jaime concede a Guillem Mir, letrado de la ciudad de Murcia, la Asesoría de la Procuración del reino de Murcia con los derechos acostumbrados y un salario anual de mil sueldos valencianos.

ACA, C, reg. 201, f. 68 r.

Nos, Jacobus, Dei gracia rex Aragonum, et cetera. Attendentes sufficienciam et industriam vestri, Guillermi Mir, iurisperiti Murcie, vobis officium Assessorie Procuracionis regni Murcie usque ad nostrum beneplacitum duximus comittendum, ita quod vos sitis assessor procuratoris dicti regni et exerceatis officium ipsius bene et legaliter. Nos enim 
mandamus per presentes procuratori et universis et singulis dicti regni quod vos pro assessore habeant dum nobis placuerit, ut est dictum, denique volumus et concedimus vobis quod habeatis et percipiatis quolibet anno pro salario seu labore vestro mille solidos regalium Valencie quos vobis solvi mandamus per baiulum regni nostri predicti de redditibus et exitibus et aliis iuribus eiusdem regni. Mandantes per presentes Ferrario de Cortilio, baiulo dicti regni, quod de redditibus et exitibus ipsius regni solvat vobis dictos mille solidos annuatim dum fueritis in officio antedicto et apochas recepturus de quantitatibus quas vobis pro inde duxerit exsolvendas.

Data Valencie, $X V l^{\circ}$ kalendas ianuarii, anno Domini $\mathrm{M}^{\circ} \mathrm{CCC}^{\circ}$ tercio.

Petrus de Monello, mandato regio.

1304, febrero, 16. Valencia.

Jaime /l concede a Arnau de Milleres el oficio de alguacil del procurador del reino de Murcia de por vida, con los derechos y el salario habituales.

ACA, C, reg. 231 , f. $54 \mathrm{v}$.

Nos, Jacobus, et cetera, confidentes de fide et legalitate tui, Arnaldo de Milleres, te ad officium alhuatzirii procuratoris regni Murcie dum vixeritis providimus statuendum, ita quod tu sis alhuatzirius dicti procuratoris et exerceas pro nobis officium ipsum bene et legaliter dum tibi fuerit vita comes. Nos enim volumus et concedimus tibi quod habeas et percipias racione ipsius officii ea iura que per alios predecessores tuos in dicto officio sunt recipi consueta. Mandantes per presentes procuratori et universis aliis officialibus et subditis nostris regni predicti quod te pro alhuatzirio habeant et tibi de hiis de quibus predecessoribus tuis in dicto officio respondere consueverunt et debent, respondant dum vixeritis, ut est dictum.

Data Valencie, XVo kalendas marcii, anno predicto. [Mํ CCCㅇII].

Bernardus de Aversone, mandato regio facto cum littera secreta.

10

1309, febrero, 25. Barcelona.

Jaime II reconoce que desde la recepción de los fueros de Valencia por las comunidades situadas al sur de Jijona los justicias ciudadanos deben prestar juramento ante el baile general del distrito y no ante el procurador, como era costumbre antes.

ACA, C, reg. 231, f. 60v.

Jacobus, et cetera, fideli suo Ferrario de Cortilio, baiulo nostro in parte regni Valencie, et cetera. Recepimus litteram vestram per quam significastis nobis quod homines de Oriola et homines Elchii elegerunt iusticias in locis ipsis die nativitatis Domini proxime 
nunc transacte et quod, licet iuxta forum Valencie ipsi iusticie in posse vestro die eadem deberent iurare et vos circa hoc requisivissetis eosdem, dicti tamen homines fecerunt iurare ipsos iusticias in posse procuratoris nostri, ut iuxta eorum privilegia antiquitus, ut asseritur, facere consueverant quodque post dies aliquos ad vestri instanciam prefati homines, recognoscentes forum Valencie in prestacione iuramenti predicti non fuisse servatum, recurrerunt ad vos ut reciperetis iuramentum a iusticiis supradictis et petierunt ac vos rogarunt instanter ut a nobis obtineretis litteram per quam concederemus ut processus coram dictis iusticiis seu per eos facti seu faciendi propter non observatum forum in prestacione iuramentorum, predictorum non possent ullo tempore anullari. Unde premissis plenarie intellectis, quia pro parte dictorum hominum suplicastis nobis ut huiusmodi litteram concedere et vobis dirigere dignaremur, volentes dicti supplicacioni annuere, per presentem litteram volumus et concedimus quod racione prescripta processus aliqui facti vel faciendi per dictos iusticias vel eorum alterum revocari non possint seu aliquatenus anullari dum modo iidem iusticie statim receptis presentibus dictum iuramentum in posse vestro faciant, nisi iam ipsum fecerint, videlicet in posse vestro ut est de foro Valencie faciendum. Quodquidem iuramentum volumus decetero fieri in posse vestro seu alterius qui pro tempore baiulus noster in ipsis partibus fuerit per iusticias locorum predictorum cum electi fuerint iuxta forum.

Data Barchinone, oo kalendas marcii, anno Domini Mo CCCo octavo.

Bernardus de Aversone, mandato regio. 